\title{
A recursive dynamic computable general equilibrium analysis of value-added tax policy options for Nigeria
}

\author{
Alarudeen Aminu*
}

${ }^{*}$ Correspondence: alarudeen@yahoo.com; a.aminu@ui.edu.ng Department of Economics, School of Economics, University of Ibadan, Ibadan, Nigeria

\begin{abstract}
The study investigates how government can implement an increase in the rate of value-added tax (VAT) to ensure that the final rate of 15\% is achieved in a way that satisfies the public (households and business community) and also ensures maximum revenue generation for the government. The nation's VAT rate is presently at $5 \%$. A recursive dynamic CGE model is used to address the study's objective, and the model is solved and simulated for 10 years. It is found that the best policy option is to increase the rate by $2.5 \%$ yearly for the next 4 years. The option delivers the best outcomes for real GDP (and its growth), investment, intermediate imports, government expenditure and household consumption when compared to alternative options that require 5\% increase (implemented in the first and fourth years) and 10\% increment (implemented in the first year). Government revenue (divided into VAT, tax and total revenue) registers the highest percentage changes under $2.5 \%$ VAT policy in the medium term (6-10 years).
\end{abstract}

Keywords: Computable general equilibrium, Value-added tax, Tax policy options, Government revenue, Welfare

JEL Classification: C68, D58, D6, E62, H22, H3

\section{Introduction}

Value-added tax (VAT) was introduced into the Nigerian federal tax system in 1994, and it has been making a substantial contribution to non-oil federally collected revenue since then. Due to the buoyancy of the tax instrument, efforts have been made since 2002 to increase its rate, which was fixed at inception and still remains at $5 \%$ of values of goods and services subject to the tax. The rate was to be increased to $15 \%$ around 2009 following the outcome of a Presidential Committee set up in 2005 to review a governmentcommissioned study team report (in 2002) on the review of the nation's tax policy. ${ }^{1}$ Other tax policy proposals for implementation around 2009 were the reductions in company income tax rate from 30 to $20 \%$ and in personal income tax rate from around 35

\footnotetext{
The increase in VAT rate was justified on the need to harmonise the country's VAT regime with what obtained in the Economic Community of West African States (ECOWAS) so as to fulfil its commitment to the regional body. VAT rates in other ECOWAS countries are 18\% in Benin, Ivory Coast, Mali, Senegal and Togo, 15\% in Ghana and 19\% in Niger (see The Nation, a daily newspaper, of 16 July 2008, pages 1, 4 and 8).
} 
to $17.5 \%$. While the reasons for the stalling of these other tax policy proposals have not been made public, the central reason for the stagnation of VAT rate at $5 \%$ has been the stiff opposition from the populace and especially the business community who are concerned about the welfare and inflationary impact of any increase in VAT rate. The same opposition attended the February 2nd (2017) Federal Executive decision to increase the rate to at least $15 \%$ on goods and services considered to be luxury items. ${ }^{2}$ The increment in VAT rate is meant to shore up the federally collected revenue, which has registered a sharp decline following the fall in the international price of crude petroleum from 2014. Federally collected revenue depends on oil-related sources (such as crude oil exports, domestic sales of refined petroleum products and petroleum profit tax) to a level of $74 \% .^{3}$

There is no doubt that government is cash-strapped at this point in time. However, it appears the government is at the same time at some sort of crossroads with respect to how to go about increasing its collectible revenue especially from VAT, which has remained an alternative and a buoyant source of non-oil revenue against the background of limited prospects of any sustainable increase in oil-related revenue sources as the forces driving the oil sector revenue are outside the contour lines of control of government. Since 2009, the proposals/decisions to increase VAT rate to bolster government revenue have been revolving around $5 \%$ and $10 \%$ without in-depth studies conducted to shed light on the impact of the rates with a view to engaging the opposing public on the way forward.

Most studies on the impact of implemented/proposed VAT policy have more often employed macroeconomic modelling approach in the mould of computable general equilibrium (CGE) modelling. To the best of my knowledge, no study that utilises CGE modelling on VAT policy for Nigeria has addressed the present policy problem faced by the government, and again, none of the studies on VAT policy for Nigeria is as rigorous in analysis as the present one. Among such studies is Ajakaiye (1996), which employs a static CGE model to assess the macroeconomic effects of VAT in Nigeria. A lot of rigidities are embedded in the Ajakaiye's model, which sort of mimic a run-of-the-mill input-output model. The study revolves around the effects of feasible approaches for treating VAT payment by organisations remitting the tax collected and the implication of the dominant approach, which considers VAT as a production cost item that needs be added to arrive at average unit cost/price. The other related study is Ekeocha (2011), which estimates macroeconomic and sectoral effects of increasing VAT rate from 5 to $15 \%$. The study never considers other alternative options that can as well be explored to shed light in a comparative sort of way in implementing the increment in the rate of the tax. A study that tries to consider feasible options for implementing the increment in the VAT rate from 5 to $15 \%$ is Aminu (2007). The study considers only $2.5 \%$ and $5 \%$ increases in VAT rate for only short run (4 years) without an explicit comparison with base run results.

\footnotetext{
${ }^{2}$ See Daily Trust, a daily newspaper, of 3 February 2017, which featured, on its front page, the decisions of the Federal Executive Council meeting held on February 2nd, 2017, to consider a new tax policy called the Revised National Tax Policy (Media Trust Limited: Abuja). It is interesting to know that the list of the so-called luxury items and their volume/ value have not been made public.

3 See the discussion under Sect. 2 of this study.
} 
The present study is a step ahead of the earlier ones (on Nigeria) with respect to addressing the present fiscal policy problem by examining some feasible options for implementing the increment in the tax rate in a recursive dynamic computable general equilibrium framework that takes into consideration the sectoral, macroeconomic and welfare impact of various policy options to increase the VAT rate over a period of 4 years that will sort of ensure that the rate settles at $15 \%$ as desired by government and as it obtains in other countries in the Economic Community of West African States. ${ }^{4}$ The model is simulated for 10 years under each of the policy options to facilitate some comparison of their impact from short to medium term. It is only labour that is mobile in the short term, while all the factors are mobile in the medium term. The policy options considered are $2.5 \%, 5 \%$ and $10 \%$. Each of these options is first compared with businessas-usual or base run ( $0 \%$ increment) policy option before a comparison/ranking is made among the class of feasible options for increased VAT revenue. The study finds that the best policy option is to increase the VAT rate by $2.5 \%$ every year for the next 4 years. The option results in the highest real GDP (and growth), investment and sectoral output, and it equally ensures the least decline in household consumption/expenditure, while it makes government expenditure (real) to register the highest percentage increment over the ten-year period. While the three policy options tend to generate the same amount of VAT revenue from the fourth year as they give rise to the same rate (that is, $15 \%$ from fourth year), the best outcomes with respect to total tax revenue are associated with the $2.5 \%$ VAT policy when the entire period of simulations is considered. It is equally interesting to find that the $2.5 \%$ VAT policy option will result in the highest positive percentage changes in VAT revenue, tax revenue and total government revenue in the medium term (6th-10th year).

The rest of the study is structured into six sections starting from Sect. 2, which describes the Nigerian economy, its tax portfolio and VAT system. Section 3 reviews a number of CGE studies devoted to analysing the impact of VAT policy on the economy. Section 4 describes the features of the recursive dynamic CGE model used in the study, while Sect. 5 focuses on the results of model simulations based on the feasible options for implementing increases in the VAT rate. Section 6 concludes and proffers some policy recommendations. The last Section contains a listing of model equations and results' tables.

\section{The Nigerian economy, its tax portfolio and value-added tax system}

\subsection{The Nigerian economy and its tax portfolio}

The nation's economy is dominated by activities of such sectors as agriculture, oil and gas, wholesale and retail trade, information and communications, and services (including transportation services) as they collectively account, on average, for $82.73 \%$ of gross domestic product (GDP) in the last couple of years (2010-2017). Each of the sectors contributed a minimum of $10 \%$ of GDP. From 1981 to 2004, manufacturing sector was one of the five key sectors of the economy among such other sectors as agriculture, oil and gas, wholesale and retail trade, and services. It was not until 2009 that information

\footnotetext{
${ }^{4}$ See footnote 1 for one of the propelling reasons for the proposal to increase the VAT rate to $15 \%$ in Nigeria.
} 


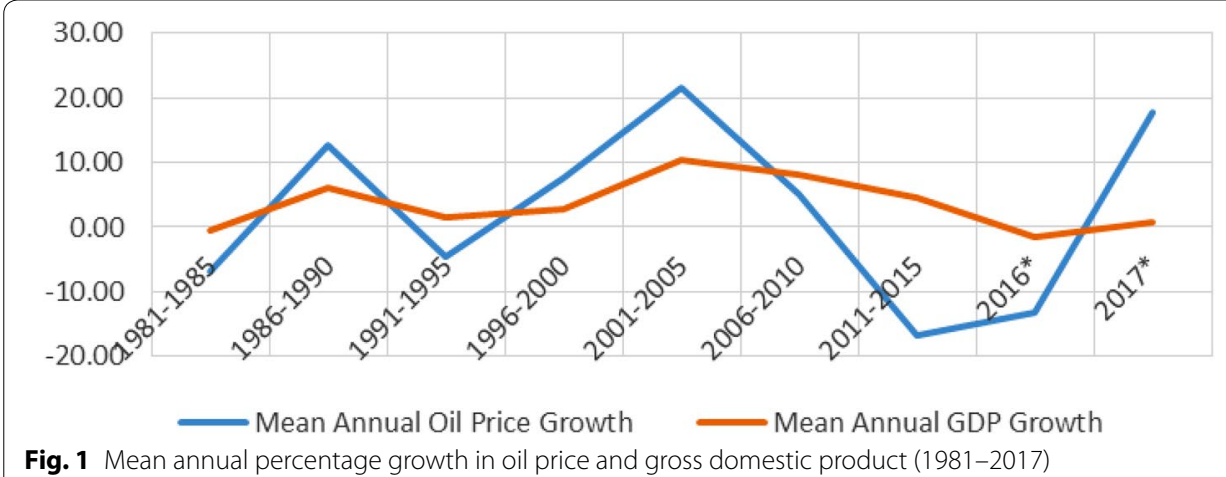

and communication sector started to contribute a minimum of 10\% of GDP having risen from $2.99 \%$ in 2000 shortly before the drastic improvement brought about by the launch of global system of mobile communications in 2001. Domestically, these sectors dictated the trend in aggregate economic activity, while externally, it is the crude oil exports that had sort of dominated the export portfolio to the level of $95.79 \%$ (on average) from 1981 to 2017 (see Central Bank of Nigeria, 2018).

The size of the economy has been fluctuating from time to time due to the fluctuation in the price of the main export commodity. As at 1981, the real GDP was N15.3 trillion and by 1990, it had only risen to N19.3 trillion, while a number of fluctuations were registered between the two years on account of the 1982-1986 recession and the implementation of Structural Adjustment Programme from the middle of 1986. The real GDP increased to N23.7 trillion and N63.2 trillion in 2000 and 2013, respectively, but declined to N68.5 trillion by the end of 2017 after attaining a peak level of N69.8 trillion in 2015 due to the economic recession that occurred in 2016. It is interesting to know that following the rebasing of GDP in 2013, the nation's GDP was estimated at $\$ 510$ billion and was adjudged the highest in Africa followed by that of South Africa ( $\$ 366.8$ billion). Recent statistics still has it that the nation is maintaining the lead. ${ }^{5}$

The growth of the economy has equally been subject to the ups and downs in the international price of crude oil given the extreme dominance of oil exports in the export portfolio. In fact, what goes on at the external sector appears to dictate the health of the domestic economy as displayed in Fig. 1. It is mean annual growth that is computed for each 5 years up to 2015, while it is yearly growth that is calculated for the last 2 years of 2016 and 2017.

It appears the increase in growth of oil price in the second half of 2011-2015 period was not strong enough to pull up GDP growth from a declining trend that commenced in 2001-2005 period and it was not until 2016-2017 period that a sort of dramatic growth in oil price could exert a small growth in GDP as displayed in the figure. In fact, the correlation coefficient between the indices of real GDP and price per barrel of crude oil is estimated to be 0.77 during the period 1981-2017. There is thus no doubt that the growth in real GDP is associated with the movement in oil price.

\footnotetext{
${ }^{5}$ See https://www.icirnigeria.org/nigeria-remains-africas-largest-economy-imf/.
} 
The collectible revenue of government is also subject to the development in the international crude oil market as oil-based revenue (oil export, domestic oil sales, petroleum profit tax and royalties) accounts, on average, for $73.69 \%$ of government revenue from 1981 to 2017. The federal government tax system is made up of company income tax, value-added tax, import duties, excise duties, petroleum profit tax, education tax, personal income tax, capital gains tax, withholding tax and stamp duties. It is, however, the first five taxes that are distributed federally among the three tiers of government (federal, state and local governments). The shares of the federally collected revenue (including oil export revenue less $13 \%$ as derivation for oil-producing states) that go to federal, state and local governments are $48.5 \%, 26.7 \%$ and $20.6 \%$, respectively, while the rest (4.2\%) goes into ecological fund and other first line charges. The education tax is collected at the federal level but channelled into infrastructural development across the federal and state-owned tertiary institutions. Another tax instrument whose revenue is not distributed across tiers of government is national information technology development levy, which is specifically collected and meant for the development of the information and communications sector.

The percentage contributions of non-oil taxes to the government tax revenue pool from 2001 to 2015 are as follows: value-added tax $-29.67 \%$, company income tax$32.32 \%$, customs and excise duties- $31.16 \%$ and education tax-5.47\%. However, when petroleum profit tax and royalties are considered, the non-oil taxes' percentage contributions will be value-added tax-14.17\%, company income tax-15.91\%, customs and excise duties $-15.10 \%$ and education tax $-2.70 \%$. This shows that oil-related taxes contributed an average of $51.44 \%$ of government tax revenue during the period (see Federal Inland Revenue Service, 2019 and Nigeria Customs Service, 2019).

Each of the main non-oil taxes especially the ones that were in existence as at the inception of value-added tax in 1994 had registered impressive growth over the period 1994-2015. ${ }^{6}$ The mean annual growth rates recorded by the taxes (in real terms) are: personal income tax: $92.69 \%$, company income tax: $112.40 \%$, customs and excise duties: $104.04 \%$ and value-added tax: $111.57 \%$. It is of interest to know that value-added tax revenue growth (in real terms) is in the neighbourhood of that of company income tax, which has been in existence since the commencement of colonial administration at the beginning of the twentieth century. In the first year (1994), value-added tax revenue (in current naira) was N20.761 billion but rose to N58.470 billion in 2000. It increased further to N564.892 billion in 2010, and at the end of September 2017, it had climbed to N701.634 billion (see Federal Inland Revenue Service, 2019).

In recent times, efforts have been intensified to broaden the bases and rates of some of the taxes especially the personal income tax, value-added tax and excise duties. ${ }^{7}$ All these are borne out of the need to increase the entire tax revenue as a percentage of GDP from less than $10 \%$ to at least $15 \%$ and also the need to lessen the dependence on

\footnotetext{
${ }^{6}$ Education tax was not in existence during 1994 fiscal year.

7 Personal income tax coverage is being extended through the voluntary asset and income declaration (VAID) policy of the Federal Ministry of Finance, while value-added tax rate is under consideration for the purpose of increasing its rate. Excise duties rates on some tobacco and alcoholic drinks are proposed to be increased in phases, but implementation is being stalled at parliament (see https://www.vanguardngr.com/2018/06/fg-approves-new-excise-duty-rates-alcoholicbeverages-tobacco/).
} 
oil-based revenue sources, which are more often subject to fluctuations induced by the instability of oil price in the international market. An integral aspect of the attempt to lessen the dependence of government collectible revenue on oil-based sources is the efforts that are being made to increase the rate of value-added tax to generate additional revenue and the tax has the tendency to generate a huge revenue across a large number of goods, services and expenditures.

\subsection{The Nigerian value-added tax system}

The introduction of VAT into the nation's fiscal space in 1994 followed the recommendations of a federal government committee on the feasibility of such a tax as far back as 1991. The tax was meant to replace sales tax, which was earlier introduced in 1986 to supplement the portfolio of taxes collected at the state level. While VAT is collected by the federal government (through its agency, the Federal Inland Revenue Service), its proceeds are shared among the three tiers of government (federal, state and local). The rate of value-added tax has been at $5 \%$ of goods and services that are subject to VAT. The VAT in operation in Nigeria is the product type, and the method of computation is credit in which the amount of VAT charged has to be explicitly stated on the invoice of the taxable transaction. ${ }^{8}$

Any business entity/individual whose activities (sales and purchases) are subject to VAT is expected to register with the VAT office in his/her area of operation in the first 6 months of the start of business. It is a mandatory requirement for any business entity/ individual who wants to engage in any transaction with any tier of government in Nigeria to show a documentary evidence of VAT registration together with evidence of past remittances of VAT to the VAT office. Non-resident entities are equally required to get registered with the VAT office using the address of the entity with which it is transacting business in Nigeria. Any communication that relates to VAT is made with the Nigerian partner's address. The non-resident entity that has registered with VAT office is required to include VAT in their invoices to the person/entity it is dealing with in Nigeria and the VAT is expected to be remitted in the currency of the contract/business.

VAT payers (especially business entities) are expected to calculate the amount of VAT they received from their customers in a month and then set it off against the VAT they paid during the same period. If the VAT paid is more than the VAT received, a refund will be established but will be netted out from VAT liability in the subsequent month. A VAT payer will have to remit the excess of his collection over payment to the VAT office by the 30th day of the month following the month the goods and services were sold/purchased. A penalty of N5000 per month is imposed on any defaulter.

Over the years, the federal government has had to broaden the coverage of the tax in a bid to increase non-oil revenue. Of particular importance is the reform that constituted the fulcrum of the tax broadening policy in 1999 fiscal year. The reform led to the removal of some items from the exemption list. The items were commercial vehicles,

\footnotetext{
${ }^{8}$ In the Nigerian case, this requires the application of destination principle in which all expenditures (except government wage expenditure, which is said to be infeasible to tax under any variant of VAT) on gross domestic product adjusted for trade balance such that all imports are subject to VAT, while exports are not. However, in the case of Nigerian VAT, household expenditures on certain goods and services are not subject to VAT. Other types of VAT are consumption and income (see Zee 1995:86).
} 
airplanes, ships, locomotives and spare parts, newspapers and magazines, and water treatment chemicals. At present, the items that are still exempted include medical and pharmaceutical products, basic food, educational materials, baby products, agricultural equipment and veterinary medicines, agricultural fertilisers and goods meant for export. Also exempted are services rendered by microfinance banks, mortgage banks/ institutions and plays and performance emanating from educational institutions as part of learning and religious service.

\section{A review of studies on CGE analysis of value-added tax policy}

Empirical studies on value-added tax policy that employ CGE methodology have focused mainly on welfare, income distribution and incidence implications of the tax with some occasional attention devoted to revenue and output effects. Most of the studies have been carried out under a dynamic applied general equilibrium context. One of such studies is Erero (2015), which delves on the effects of increases in value-added tax in South Africa using a recursive dynamic CGE model. The study implements five simulations that involve increases in VAT rate from 1 to 5\%. A major finding of the study is that the percentage increase in the tax rate will not impoverish the lower-income households if the increased revenue is channelled (in the form of provision of social services) to them. The standard of living of both the middle- and high-income households increases together with a marginal increase in gross domestic product. Government revenue also increases. Erero's (2015) findings are in conformity with those of an earlier study by Kearney and van Heerden (2003) on the same country. Another related study on South Africa with similar findings is carried out by Go, Kearney, Robinson and Thierfelder (2005). The study finds that the tax is slightly regressive, while it is equally found to be an effective tax instrument for generating revenue among a class of tax instruments in the kitty of the fiscal authority.

Bye, Strom and Avitsland (2003) develop an intertemporal CGE model to estimate the relative welfare effects of uniform and differentiated VAT rate policies in Norway. It finds that the latter VAT rate policy results in welfare loss when compared with the former. The different VAT rate reform which is christened political VAT reform was introduced in 2001. In a related study, Carroll et al. (2010) use a dynamic CGE model of the United States of America (USA) to estimate the macroeconomic effects of an add-on value-added tax. The introduction of VAT by the government of the USA is considered as one of the two policy options that can be used to reduce the fiscal deficits by $2 \%$ of GDP. The endogenously derived VAT rate that will achieve the deficit reduction is $10.3 \%$, which eventually results in lower deficits and debt with some positive long-run impact on the economy. However, the study finds that the tax will reduce retail spending by $\$ 2.5$ trillion over the next 10 years, while GDP will decline for several years with 1.550 million jobs lost over an 11-year period with the highest loss occurring in the first year $(850,000)$. The majority of Americans over 21 years will be worse off, and there will be some reduction in the real income and employment for existing labour market participants. An alternative policy option which involves a reduction in government expenditure to achieve a deficit reduction of $2 \%$ of GDP will generate 250,000 new jobs. A case 
is made for the latter policy option, perhaps to underline the position of the sponsor (National Retail Federation) of the research.

Giesecke and Tran (2009) develop a framework for economy-wide modelling for value-added tax systems. The framework embraces multiple rates, multi-product enterprises, multiple exemptions and multiple grades of refundability across commodities. They use the model to investigate the impact of replacing multiple VAT rates with a single rate, removing exemptions and lowering of administrative and compliance costs in a dynamic general equilibrium context. The analysis is implemented in a revenue-neutral framework for 12 years. It is found that real private consumption (measure of welfare) increases by $0.9 \%$, on average, in relation to the base run. A third of the increase is traceable to the first two reforms, while the rest is accounted for by the last set of reforms. Capital accumulation also increases especially in the housing sector, which registers $1.4 \%$ increase (on average) in the stock of housing with a reduction of $1.6 \%$ (on average) in the sector's price.

Felici and Gesualdo (2014) extend the VAT framework by Giesecke and Tran (2009), which relates to modelling multi-production, multiple VAT rates, multiple VAT exemptions, differential VAT registration rates, undeclared imports, unclaimed VAT on tourist's purchases and general and transaction-specific compliance rates. The study specifically includes fiscal details into an existing CGE model (ORANI-IT). They include in their model's database such specific Italian economic features as the non-taxable public sector and some differentiated taxation of what they refer to as intra-community and extra-community exports. There is, however, no simulation of any sort. ${ }^{9}$

Emini (2004) investigates the difference that may exist between short-run effects and long-run effects of implementing a value-added tax policy under a general equilibrium framework for Cameroon. The short run is characterised by mobility of only labour across sectors of the economy, while the long run is identified with mobility of both labour and capital. The central focus of the study is an analysis of welfare and resource allocation effects of VAT policy options. It finds that an imperfect VAT policy (the one with exemptions and differential rates) can be welfare improving in the short run but will spurn welfare deterioration in the long run. On the other hand, under a pure VAT policy (the one anchored on uniform rate without exemptions), any welfare gain in the short run becomes magnified in the long run, while any welfare loss in the short run turns to welfare gain in the long run. It is also found that resources (production inputs) flow to sectors that bore a higher burden of tax before a VAT policy is implemented.

Nakamba-Kabaso (2010) examines the reform of VAT in Zambia. The study addresses a twofold issue related to broadening the tax base to all sectors and broadening the tax base to the agricultural sectors except the maize sector which is central to the country's staple. The study finds that VAT is mildly regressive, while it places a higher burden on the urban households than it does on the rural households especially with regard to the VAT paid on food. Another one finding is that broadening the VAT base to all sectors results in additional revenue with some adverse effects on the economy (welfare-wise) in the short run. The deleterious effects on the economy are ameliorated in case a VAT

${ }^{9}$ It is quite obvious that the paper never attempts any policy simulation and this is even well acknowledged in the authors' closing remark that 'further researches may be pursued in policy simulations' (see Felici and Gesualdo 2014:27). 
broadening policy is characterised by a reduction in the VAT rate, while a broadening policy, which encompasses agriculture with the exemption of maize will result in some minimal effects on the economy and also result in an increase in revenue with some adverse effects on the welfare of urban households. Again, broadening the VAT base triggers a reallocation of resources within the value-added in favour of the mobile factor (labour) due to the impact of rebates on relative prices of intermediate inputs. Another outstanding finding is that welfare losses from broadening the VAT base fall with an improvement in the functioning of the rebate system.

A related VAT study to the earlier one is that of Levin and Sayeed (2014), which delves on distributional impact of VAT imposition that allows exemptions and the one that does not for Bangladesh. The study finds that VAT without exemptions causes tax incidence to be higher for the poor households, while VAT imposition that exempts local market food sectors ensures that equivalent variations of low-income groups in both the rural and urban areas become bolstered. The study thus suggests a VAT system that stresses exemptions for local food sectors.

In a CGE study carried out by Sajeewani and Meng (2017) on the potential macroeconomic and welfare effects of the introduction of VAT of 5\% rate in the six Gulf Corporation Council countries, ${ }^{10}$ it is found that government revenue will rise without any significant impact on growth, while an across-the-board VAT (covering all goods/services) is found to be more efficient than the selective VAT policy being proposed by the countries. The CGE model used in the study is that of the world in the mould of Global Trade Analysis Project (GTAP) model in its static form.

Ajakaiye (1996) appears to be the first study that employs CGE model to estimate the macroeconomic effects of value-added tax in Nigeria. The policy issues addressed are the effects of VAT under different treatments by taxpayers and also under different fiscal policy stances. The study considers specifically situations when there is no problem of cascading in VAT treatment combined with an active fiscal policy (when government spends VAT revenue, thereby leading to an increase in its consumption expenditure); when there is no problem of cascading under a passive fiscal policy; and when there is problem of cascading (when VAT is treated as part of production cost by taxpayers) coexisting with an active fiscal policy disposition. The simulation exercise shows that, if VAT paying organisations treat the VAT in a way that will not lead to the problem of cascading, all sectoral prices and the general price level will increase by $5 \%$; but, the effects on such key economic variables as consumption expenditure, output, factor incomes and its functional distribution, private, government and foreign savings depend on the fiscal policy stance with respect to the use of VAT revenue. The study observes (through a survey of VAT payers by the author) that majority of VAT payers treat the tax as part of cost, and so, the result obtained best approximates the Nigerian situation. At the end, it is argued that it is necessary to consider strategies for securing appropriate treatment of VAT by VAT paying organisations, while taking steps to ensure that the VAT revenue

\footnotetext{
${ }^{10}$ Gulf Corporation Council came into being in 1981 and is made up of Kuwait, Qatar, Saudi Arabia, United Arab Emirates, Bahrain and Omar. It is a council that seeks to strengthen economic and social interactions between member countries.
} 
is targeted at sectors most likely to ameliorate the adverse effects of VAT on consumer welfare, production, employment and income.

A related study on VAT policy for Nigeria is Aminu (2007), which examines the relative effects of effecting a $2.5 \%$ and a $5 \%$ increase in VAT rate on the economy and the households over a period of 4 years so that the tax rate remains at $15 \%$ by the end of the period. A recursive dynamic computable general equilibrium model is used to achieve the objective. The study is part of a Millennium Development Goals-based Generic Macroeconomic Framework for Nigeria under the auspices of the Nigeria's office of the United Nations Development Programme and National Planning Commission. The underlying Social Accounting Matrix database is populated with input-output table for 2004, poverty survey (which contains households' classification into six socio-economic groups) for 1999, government finances as at 2004, VAT laws, and tariffs and excise duties schedule. ${ }^{11}$ Each sector of the economy employs labour and capital in the production process. The price of labour (wage rate) is the model's numeraire, while capital is assumed to be immobile as the period of analysis is of short duration. The study finds that real gross domestic product (RGDP) increases slightly by $0.65 \%$ (on average) under a $5 \%$ increment (in VAT rate) in the first and fourth years, while a decline of $0.12 \%$ (on average) in RGDP is registered under a $2.5 \%$ increase every year over a four-year period. VAT revenue increases (on average) the more under a $5 \%$ increase $(37.54 \%$ ) than under a $2.5 \%$ increase $(25.87 \%)$ in VAT rate. Real exchange rate decline is higher under a $2.5 \%$ increment $(-4.43 \%)$ than under $5 \%$ increase $(-1.28 \%)$ in the tax rate. The six households' groups are better off under a $2.5 \%$ increase in VAT rate, while the groups (except the rural poor) are worse off when a $5 \%$ rise is implemented.

Still on Nigeria's VAT policy, Ekeocha (2011) investigates the potential economic effects of increasing value-added tax rate from 5 to $15 \%$ using Orani-G CGE model with 1999 social accounting matrix. The motivation for the exercise is the National Tax Policy that was released in January 2010, which provides for reductions in company income tax rate from 30 to $20 \%$ and in personal income tax rate from 25 to $17.5 \%$. The tax policy also requires an increase in value-added tax rate from 5 to $15 \%$ to ensure that the nation's tax system leans more on indirect than direct tax sources with a view to releasing more resources to the private sector for increased investment expenditure to spur growth in the economy. The study finds that there will be a slight decline in real gross domestic product with increased indirect taxes' (including VAT) revenue. A large number of sectors register increases in their output. There is, however, some methodological problem in the model simulations and the accompanied results as the base run solution values for variables are interpreted as one set of counterfactual.

\section{A recursive dynamic CGE model of Nigeria}

The CGE model, in its static form, is an open-economy, single-country model, which treats the rest of the world (besides Nigeria) as a single economic region/agent. The model has five producing sectors and six households. The sectors are agriculture, crude oil-gas-mining, manufacturing, utilities and services. Each of the sectors is an

${ }^{11}$ The households' groups in the survey are urban non-poor, urban moderately poor, urban poor, rural non-poor, rura moderately poor and rural poor. 
aggregation of related activities using the social accounting matrix (SAM) derived in part from Nigeria's 2011 input-output. For instance, agriculture in the model includes such related activities as crop production, fishery, livestock and forestry. One central reason for having five activity/commodity sectors in the SAM and model is that there are some sectors in the disaggregated 2011 input-output table that have zero values for intersectoral flows. By aggregating the sectors into five ensures the sidestepping of problems posed by such zero intersectoral flows. One of such problems is zero values for a large number of cells in the technological matrix, which can render any general equilibrium analysis of policy shocks an exercise of no value.

The households are urban non-poor, urban moderately poor, urban poor, rural nonpoor, rural moderately poor and rural poor. The household classification is the one used in the household survey that constitutes the fulcrum of poverty profile of Nigeria as at 2010. Each of the sectors is tradable (as it supplies both domestic and foreign markets), and there is also import transaction in every sector. This structure of the model is informed by Armington assumption, which relates to the notion that imports and domestic supplies of the same sector are imperfect substitutes. ${ }^{12}$ Each sector's commodity is consumed in a composite form (imported and domestically produced varieties) using a constant elasticity of substitution function that responds to the relative prices of the sector's domestic and competing imported counterparts, while each sector's output is supplied to the domestic and foreign markets using a constant elasticity of transformation function that is sensitive to the relative prices of domestic and foreign supplies.

Each sector's producer is assumed to maximise profits subject to a Leontief production function in which intermediate inputs (domestic and imported) are combined with labour and capital to yield final output. Labour and capital are the two inputs used in the value-added production with constant elasticity of substitution (CES) technology. Each household maximises a Cobb-Douglas-type utility function that is subject to income derived from supplying labour and capital for production activity. ${ }^{13}$

Each producer/sector buys intermediate goods (domestic and import) and pays for the use of labour and capital inputs. The producer also pays such taxes as VAT, import duties, excise duties and petroleum profit tax, while the firms as an institution pay company income tax to the government. The data on these taxes in 2011 are incorporated into the SAM used for the study. Each of the producers makes provision for depreciation of capital equipments. The depreciation is a form of savings, which, of course, goes into the nation's savings pool. Other savings in the model include those of the six household groups, firms (in the form of retained earnings), rest of the world and government. The savings pool finances investment across the producing sectors. The level of investment in the model depends on that of savings, thereby making the investment to be savings-driven. The sort of rule guiding the investment in this study is called neoclassical closure rule. The closure rule is more realistic than the Kaldorian closure rule in the Nigerian context as the amount of financial resources mobilised domestically and

\footnotetext{
12 See Armington (1969) for a detailed exposition of the assumption.

13 It is the income left after subtracting savings from household's gross income from labour and capital services supplied.
} 
externally (through the instrumentalities of foreign grants, aids and loans, and also by way of excess of imports over exports) determines the level of domestic investment in every fiscal year and development plan. ${ }^{14}$

Capital as an input in the production process is assumed to be immobile across sectors at least in the short run during which the policy options are to be implemented and diffused across the nooks and crannies of the economy. ${ }^{15}$ The short-run period is five years in the process of solving and simulating the model. However, in the medium term (6-10 years), capital is assumed to be mobile. Two approaches to modelling capital mobility which stress mobility of new capital in the nature of investment are experimented with before the choice is made on full capital mobility. ${ }^{16}$

Another characteristic feature of the model is the way in which the value-added tax is incorporated into the model. According to the Nigerian VAT law, all imports are subject to VAT, while some domestically produced and sold goods are exempted. Details of commodities that are exempted are given in the VAT law and revised versions of the law are briefly described under Sect. 2.2 of this study. Exports across sectors and most agricultural commodities/equipment are exempted and they bear $0 \%$ VAT rate. This is incorporated into the model by assigning zero VAT rate on agriculture sector's output and all exports across sectors. There is also the problem of cascading in VAT treatment by payers especially the manufacturers and business entities. In an earlier study by Ajakaiye (1996), it is observed that VAT payers (manufacturers/business entities) treat the tax as a production cost item, thereby resulting in the phenomenon of cascading. The cascading nature of VAT treatment in Nigeria was further confirmed from personal interviews this author had with staffers of the Federal Inland Revenue Service in the commercial cities of Ibadan, Lagos and Abuja. The phenomenon of cascading will thus make some commodities suffer VAT imposition more than once before they are finally consumed. Given the possibility that the chain of cascading may be long in the process of collecting the tax, it may therefore not be possible to know the categories of commodities and the number of times the commodities will be subject to VAT. However, from what obtains in the Nigerian business environment, it is safe to categorise imported commodities as the ones most likely to suffer this problem of cascading and it is equally plausible that the imported commodities will be subject to VAT twice at the minimum. The first point of VAT imposition on imports is at the border, while the second point will most likely be at commodities' markets within the country. Hence, in this model, imported commodities' VAT rate is twice the prevailing VAT rate.

The recursive character of the model is anchored on a series of equations that updates the values of some variables and the character is equally manifested through the use of terminal values of variables and parameters in 1 year as starting values for another

\footnotetext{
${ }^{14}$ The Kaldorian closure rule is the one in which savings adjust to a fixed level of investment. This closure rule has featured in earlier CGE models on Nigeria [see Ajakaiye (1996), Aminu (2006, 2007)].

15 Most CGE models on developing countries more often than not assume that capital is immobile across sectors to underline the fact of the underdeveloped nature of their capital markets unlike what obtains in the developed countries. Again, in the short run, producer theory shows that at least one factor of production will remain fixed.

16 Each of the two approaches [see Dervis et al. (1982:177) for one approach and Erero (2015:9) for the other, which is a derivative of the first approach] results in negative capital stocks for two sectors and these sort of obstruct feasible solution when the model is solved/simulated in the medium term with the inclusion of an equation describing investment mobility (in a proportional sense) to sectors with higher profitability indices.
} 
year's solution and simulation. The variables whose values are updated are foreign savings, labour, capital and oil sales (domestic and foreign). While foreign savings and labour are kept constant in per capita terms, capital for each subsequent year is capital plus investment minus depreciation for the previous year. Oil sales as a source of government revenue are assumed to grow by a minimum of $10 \%$ per annum. ${ }^{17}$ VAT rate is equally updated depending on the VAT policy option being implemented, but the base run or business-as-usual solution assumes $0 \%$ increase in the tax rate, which is retained at $5 \%$. A new equation is introduced in the sixth year to model the capital mobility in the medium term.

As mentioned in the introductory section, three VAT policy options are considered and these are $2.5 \%, 5 \%$ and $10 \%$ within a period of 4 years. While there are justifications for considering 5 and 10\% VAT policy options, the $2.5 \%$ is chosen for consideration on two grounds. First, some lower rates (than 2.5\%) were experimented with and found to be inferior (in terms of impact) to $2.5 \%$ except rates that are very close to $2.5 \%$. Second, the $2.5 \%$ rate is half of the $5 \%$ rate and it should be of interest to compare the impact under the two rates. Another case for considering 2.5\% is the empirical finding in Aminu (2007), which relates to the macroeconomic implications of implementing such a policy option, and there is therefore a need to explore further its macroeconomic, sectoral and welfare implications in a longer period context. ${ }^{18}$ Both the $5 \%$ and $10 \%$ increments in VAT rate had been proposed before now by the government without any study conducted to shed light on their implications for the economy, firms and households (see the discussion under Sect. 1 of this study). It should therefore be a matter of course to explore and carry out simulations of the implications of each of the rates (5\% and $10 \%)$ for the economy, firms and households.

Under the $2.5 \%$ VAT policy, the current VAT rate (5\%) is increased by $2.5 \%$ every year for the next four years so that the final rate converges at $15 \%$ by the fourth year. Under the $5 \%$ VAT policy, the tax rate is increased by $5 \%$ in the first and fourth years so that the final rate is $15 \%$ in the fourth year. The implementation of the $10 \%$ VAT policy requires an increment of $10 \%$ in VAT rate in the first year so that the tax rate is $15 \%$ from first year, thereby ensuring that each of the three VAT policy options results in a VAT rate of $15 \%$ from fourth to the last year (tenth) of model solution/simulation. The base run solution of the model assumes no change in the VAT policy, which means that the existing VAT rate of $5 \%$ prevails from the first to the last year (tenth). The base run solution and policy simulations of the model are obtained using General Algebraic Modelling System (GAMS) software. A listing of the model's equations is given in "Appendix".

\section{Results from model simulations}

The results of simulations under each of the VAT policy options are discussed from the aggregate to the sectoral level. First and foremost is the set of results that are related to government revenue, which shows a marked improvement under each of the policy options from the first to the last year.

\footnotetext{
17 The $10 \%$ growth assumed for oil sales revenue is a conservative estimate as its mean annual growth from 1981 to 2017 is $18.71 \%$, while its average growth rate is $28.25 \%$ within the same period (see Central Bank of Nigeria 2018).

18 The period covered in Aminu (2007) is shorter (4 years) than the period of analysis in this study.
} 


\subsection{Impact of VAT policy options on government revenue}

It is the $2.5 \%$ VAT policy option that appears to be the best over the medium term with respect to changes in government VAT revenue, tax revenue and total revenue (see Table 1; Figs. 2, 3 and 4 in "Appendix"). There is not much difference in the impact of the three policy options on VAT revenue from the 4th year as the rates are the same as from that year. However, there is discernible differential impact on total tax revenue and total government revenue as from the 6th year following the mobility of capital as an input in the production process. On average, the percentage change in VAT revenue in the first 5 years is highest under the 10\% VAT policy (196.63\%) compared to what obtains under the $2.5 \%(139.64 \%)$ and the 5\% (136.34\%) VAT policy options (see Table 1 in "Appendix"). In the second 5-year period (from 6th year), it is the $2.5 \%$ VAT policy that delivers the highest percentage change (of 202.42\%) in VAT revenue compared to the percentage changes under the 5\% (199.65\%) and the 10\% (201.41\%) VAT policy options (see Table 1). The explanation for this may be situated in the positive impact, which the $2.5 \%$ VAT policy has on some macroeconomic variables, which culminates in the highest growth and in the highest terminal value for gross domestic product during the 10 years of simulation (see Table 2; Fig. 6).

\subsection{Impact of VAT policy options on macro-variables}

The results of simulations (during the 10-year period) with respect to changes (over the base run) in macro-variables such as real gross domestic product (RGDP), household consumption, investment, imports (intermediates and final) and exports are shown in Table 2 and Fig. 5, 6, 7, 8, 9, 10, 11, 12, 13, 14 and 15 (in "Appendix"). Table 2 shows that RGDP will register an extra growth of $0.24 \%$ (over the base run growth) under the $2.5 \%$ VAT policy, while the 5 and 10\% VAT policy options will spur additional growth of $0.19 \%$ and $0.16 \%$, respectively, over the 10 -year period. The trends in RGDP growth differential under the three policy options are shown in Fig. 5. The figure shows that the $2.5 \%$ VAT policy will result in RGDP growth differential declining in the first 3 years before rising and peaking in the 6th year and thereafter falling till the end of the period. It is the opposite trend for RGDP growth differential that will be associated with the 5\% VAT policy. The only difference in the trend in the same indicator under the $10 \%$ VAT policy compared to that of the $2.5 \%$ VAT policy is the larger negative trend in the first 3 years under the former.

In Table 2, final imports will decline by $2.98 \%$ over the ten-year period under the $2.5 \%$ VAT policy, while it will register percentage increases of $0.56 \%$ and $5.27 \%$ under the 5 and $10 \%$ VAT policy options, respectively. The average results in respect of the final imports might have concealed the impact of exchange rate depreciation, which is higher under the $10 \%$ VAT policy than under the $2.5 \%$ VAT policy. A depreciated exchange rate should ordinarily reduce imports. Figure 8 shows that final imports will have a trend of positive percentage change under the $10 \%$ VAT policy over the base run with a peak in the 5th year before declining and converging at the base run in the 10th year. The same figure shows that final imports will be characterised by a negative trend under the $2.5 \%$ VAT policy with a peak occurring in the 5 th year before converging at the base run in the 10th year. The figure shows further that the trend for the percentage change in final imports under the 5\% VAT policy will be positive in the 
first 2 years at relatively low levels, while the trend will be negative in the next 3 years (3rd, 4th and 5th) before converging at the base run in the 10th year.

Table 2 shows that intermediate imports will increase by $2.08 \%$ under the $2.5 \%$ VAT policy compared to the low positive impact of $0.94 \%$ under $5 \%$ VAT policy and the negative impact of $1.43 \%$ associated with the $10 \%$ VAT policy. The trends in the percentage change in intermediate imports are shown in Fig. 9. The figure clearly shows that it is only under the $2.5 \%$ VAT policy that the macro-variable will assume positive trend throughout the 10-year period, while it will be characterised by negative trends from the 2 nd to the 4 th year under both the 5 and 10\% VAT policy options. However, from the 5 th year, the $5 \%$ VAT policy will give rise to positive trend for intermediate imports with a peak occurring in the 6th year. It is negative trend that will constitute the lot of intermediate imports under the 10\% VAT policy from the end of the 5th year.

As shown in Table 2, exports will decline by $1.74 \%$ under the $2.5 \%$ VAT policy, while the reduction in exports that will result from the 5\% VAT policy is $0.10 \%$ compared to the percentage increase of $2.27 \%$ under $10 \%$ VAT policy. This can be explained in the light of the impact of the $10 \%$ VAT policy on exchange rate in which the policy leads to the highest depreciation of $3.19 \%$ (see Table 4). Furthermore, it appears the increase in exports under the 10\% VAT policy provides the impetus for the increase in final imports under the same VAT policy option. Again, one expects that the $2.5 \%$ VAT policy which ensures the highest positive impact on intermediate imports will sort of spur an increased positive impact on exports, however, this is not what obtains. The problem is that the nation's production activity that requires intermediate imports is inward-oriented, import substitution production and this perhaps explains, in part, the reduction in final imports especially with regard to the $2.5 \%$ VAT policy options. Figure 10 shows that the percentage change in exports is characterised by positive trend under 10\% VAT that reaches a peak in the 5th year, while it is characterised by negative trend under the 2.5 and 5\% VAT policies, respectively, with the highest decline recorded in the 5th year under the $2.5 \%$ VAT policy.

Figure 7 shows that positive trend will characterise investment under the 2.5\% VAT policy after capital becomes mobile from the sixth year, while negative trends will be associated with the 5 and 10\% VAT policy options during the same period. The trends of investment under the three policy options in the first 5 years are the opposite of what obtains in the second 5 years of analysis. Table 2 shows that investment will record (on average, over the 10 -year period) a positive percentage change of $4.83 \%$ over the base run under the $2.5 \%$ VAT policy, while the percentage change (positive) under the 5\% VAT policy is $2.75 \%$ compared to $3.15 \%$ percentage decline under the $10 \%$ VAT policy option. The percentage change in government expenditure under the $2.5 \%$ VAT policy will be $16.47 \%$ (over the base run) compared to $14.75 \%$ and $13.04 \%$ under the 5 and $10 \%$ VAT policy options, respectively. The result with regard to the $2.5 \%$ VAT policy seems to follow from the impact the policy has on government revenue. Government expenditure is influenced in large measure by the level of government revenue. Household consumption expenditure will register the lowest negative percentage change of $2.51 \%$ (over the base run) under the 2.5\% VAT policy, whereas the 5 and 10\% VAT policy options will result in $6.96 \%$ and $14.38 \%$ reductions, respectively, in the same macro-variable. 
On the whole, it appears the stellar performance of the 2.5\% VAT policy in increasing intermediate imports (which support domestic production), investment and government expenditure and the fact that the policy will lead to the least reduction in household consumption sort of rub off on the gross domestic output, which records the highest growth and level under the policy option (see Figs. 5, 6).

\subsection{Impact of VAT policy options on household welfare}

The effects of each VAT policy option are captured through the computation of equivalent variation for each of the household groups. Summing over the six household groups over the 10-year period produces the results depicted in a pie chart in Fig. 13 in "Appendix". The figure shows that the highest loss (estimated at N1280.353 billion) in terms of welfare cost is associated with the $10 \%$ VAT policy followed by the welfare loss under the 2.5\% VAT policy, which is N824.495 billion. The least welfare cost of N358.659 billion is related to the 5\% VAT policy. Table 3 and Fig. 14 show that each of the VAT policy options is regressive and this conforms (to a certain extent) to what obtains in similar studies on South Africa by Go, Kearney, Robinson and Thierfelder (2005) and on Bangladesh by Levin and Sayeed (2014). To address the regressive character of the tax instrument, there may be a need to devote part of its revenue to bolstering the income potentials and welfare of households considered to be poor. The poor are made up (in this study) of urban moderately poor, urban core poor, rural moderately poor and rural core poor following household classifications in the poverty profile of Nigeria as compiled by the National Bureau of Statistics.

\subsection{Impact of VAT policy options on exchange rate and wage rate}

The movements and the average change (over the base run) in wage and exchange rates appear to dictate the trend or structure of the equivalent variation of the households with respect to the relevant VAT policy options (see Table 4; Figs. 15, 16 in "Appendix"). This suggests in part that a VAT policy that leads to exchange rate depreciation will worsen household welfare and aggravate the regressive character of the tax. In the same vein, as wage rate (real) declines, the returns from labour supply by the majority of the households will fall, thereby affecting welfare of the households. The national currency, naira, will depreciate by $1.85 \%$ over the 10 -year period under the $2.5 \%$ VAT policy compared to $3.19 \%$ depreciation under the $10 \%$ VAT policy (see Table 4). It is only under the $5 \%$ VAT policy that the naira will appreciate by $1.99 \%$. Wage rate will decline by $3.55 \%$ under the $2.5 \%$ VAT policy, while it will decline by $6.65 \%$ with the $10 \%$ VAT policy. The least percentage decline $(1.74 \%)$ in wage rate is associated with the 5\% VAT policy.

\subsection{Sectoral Impact of VAT policy options}

The impact of the three VAT policy options on sectoral output is given in Table 5. It can be seen that the best tax policy option is the $2.5 \%$ VAT policy as it will result in a positive percentage change of $2.41 \%$ (on average) in output across sectors over the base run during the 10 -year period of simulation, while the 5 and $10 \%$ policy options will lead to $0.95 \%$ and $1.79 \%$ increases, respectively. The trends that characterise output in each sector are depicted in Figs. 17, 18, 19, 20 and 21. 
It is the 5\% VAT policy that appears to stimulate production in agriculture as positive trend characterises the percentage change in the sector's output during the ten-year period. On the other hand, both the 2.5 and $10 \%$ VAT policies will result in some positive percentage change in agriculture output in the first five years, while the policies will engender negative percentage changes in the medium term, but a lower negative percentage change will be associated with the $2.5 \%$ VAT policy (see Fig. 17). These results can be explained to a certain extent in the light of the relative impacts of the VAT policy options on sectoral investment (see Fig. 22).

A positive percentage change in crude oil, mining and quarry output will be realised under the $2.5 \%$ VAT policy from the end of the seventh year, while all the VAT policies will result in negative percentage changes in the sector's output in the first six years. Whereas all the VAT policies will stimulate production in the manufacturing sector, it is the $2.5 \%$ VAT policy that will deliver the highest percentage change in the sector's production (see Figs. 18, 19). This is understandable as the 2.5\% VAT policy results in the highest positive percentage change in investment and intermediate imports of manufacturing sector (see Figs. 24, 41). It appears the lower price/cost effect of the $2.5 \%$ VAT policy compared to what obtains under either $5 \%$ or $10 \%$ VAT policy spurs intermediate imports needed for manufacturing sector.

It can be seen that the three VAT policy options will not stimulate production in the utilities' sector, but it appears that the mobility of capital in the sixth year makes the 2.5\% VAT policy the best option in most years during the medium term (see Fig. 20). Positive trends constitute the lot of the percentage changes in services output under the three VAT policy options as shown in Fig. 21. The mobility of capital from the sixth year seems to influence the trends in percentage changes in production under the 2.5 and $10 \%$ VAT policy options. Under the 5\% VAT policy, the percentage change in the services sector's output reaches its zenith in the sixth year. On the whole, it appears that the positive trends in the percentage changes in output of some sectors under the $2.5 \%$ VAT policy are such that they make the policy option to be associated with the highest percentage change in the total output across sectors during the tenyear period.

With respect to the impact of the VAT policies on sectoral investment, it is found that the 5\% VAT policy will deliver the highest percentage change in agricultural investment in the first 5 years, while the $2.5 \%$ VAT policy will give rise to negative percentage changes in the same period (see Fig. 22). However, the $2.5 \%$ VAT policy will result in the highest percentage change in agricultural investment in the second 5 years, while the $10 \%$ VAT policy will make agricultural investment to register negative percentage changes in the same period. The 5\% VAT policy, on the other hand, will lead to a negative percentage change in agricultural investment in especially the 6 th year.

The sort of trend that characterises percentage changes in agricultural investment under the 5\% VAT policy is replicated in crude oil and mining/quarrying investment (see Fig. 23). While the percentage changes in crude oil and mining/quarrying investment in the 1st to the 10th years follow the same trend, which is negative in the first 5 years and positive in the second 5 years under the 2.5 and 10\% VAT policy options, it is the former VAT policy that will result in a combination of lower negative 
percentage change and higher positive percentage change in crude oil and mining/ quarrying investment during the 10 -year period.

Manufacturing investment will register positive percentage changes under the three VAT policy options (see Fig. 24). It is the $2.5 \%$ VAT policy option that will deliver the highest positive percentage change in the sector's investment from the 3rd year to the 10 th year. On average, the least positive percentage change in manufacturing investment is associated with the 5\% VAT policy option. On the other hand, Fig. 25 shows that all of the VAT policy options will result in negative percentage changes in utilities' investment over the 10-year period. However, the 5\% VAT policy will result in the least negative percentage change in the first 5 years and will give rise to the highest percentage change in the second 5 years. It is the $2.5 \%$ VAT policy that will give rise to the second highest negative percentage change in the first 5 years, while the same VAT policy is characterised by the least negative percentage change in utilities' investment in the medium term.

As regards services investment, it can be seen that all of the VAT policy options will result in positive percentage changes over the 10-year period as shown in Fig. 26. While it is the 5\% VAT policy that delivers the highest positive percentage change of $21 \%$ in the fifth year of the first five years, it is the $2.5 \%$ VAT policy that ensures the highest percentage change in the medium term. The least positive percentage change in the medium term will be generated by the 5\% VAT policy.

It is the $2.5 \%$ VAT policy that will result in the highest additional average growth of $1.68 \%$ in capital stock across sectors during the 10-year period, while the 5 and $10 \%$ VAT policy options will produce $1.28 \%$ and $0.01 \%$ average growth, respectively, in the same variable (see Fig. 27). Sectoral breakdown of percentage change in capital stock is presented in Fig. 28. It appears the percentage changes in capital stock of manufacturing and services under the $2.5 \%$ VAT policy are higher at least in value than what obtains under the 5 or the $10 \%$ VAT policy to the extent of resulting in the highest average growth in capital stock across sectors during the 10-year period of simulation (see Figs. 27, 28, 29, 30, 31, 32, 33).

It is the 5\% VAT policy that will produce positive percentage changes in the final imports of agricultural sector (see Fig. 34). The three VAT policy options will give rise negative percentage changes in final imports of crude oil-gas and mining/quarrying and also in the final imports of manufacturing sector (see Figs. 35, 36). On the other hand, it is the $2.5 \%$ VAT policy option that will result, on average, in the highest positive percentage change over the base run during the 10-year period with regard to final imports of utilities' sector (Fig. 37). The three VAT policy options will give rise to negative percentage changes in final imports of services' sector. The negative assumed by percentage changes in final imports of services under the 2.5 and 10\% VAT policy options fall drastically following perhaps the mobility of capital in the medium term.

With respect to the impact of the VAT policy options on intermediate imports, Fig. 39 shows that it is the $5 \%$ VAT policy option that will generate, on average, the highest positive percentage changes in the agricultural sector's intermediate imports, while Fig. 40 shows that the $2.5 \%$ VAT policy will spawn positive percentage changes (that are less than $2 \%$ ) in the intermediate imports of crude oil-gas and mining/quarrying for 3 years in the medium term. While it is observed that all of the VAT policy options will lead to 
positive percentage changes in intermediate imports of manufacturing sector, it is the $2.5 \%$ VAT policy that will deliver the highest positive percentage changes over the base run especially from the 3rd year (see Fig. 41). This can be explained with reference to the fact that the $2.5 \%$ VAT policy leads to increases in manufacturing investment, which will without doubt require more quantities of intermediate goods and other inputs to be used in the production process.

On the other hand, the three VAT policy options will be associated with negative percentage changes in intermediate imports of utilities' sector (see Fig. 42). However, the three VAT policy options will lead to positive percentage changes (over the base run) in intermediate imports of services' sector during the 10-year period of simulation (Fig. 43).

The impact of the three VAT policy options on sectoral exports is shown in Figs. 44, 45, 46, 47 and 48. Figure 44 shows that the 5\% VAT policy will cause positive percentage changes in agricultural exports in the first 5 years, while the policy will result in still positive percentage changes with declining trends in the in the medium term. The percentage changes (over the base run) in agricultural exports under the other two VAT policy options will be negative with declining trends in the medium term. Figure 45 shows that the 2.5 and $10 \%$ VAT policy options will result in positive percentage changes in crude oil/gas/mining for a few years in the medium term. The three VAT policy options will result in positive percentage changes in the exports of manufacturing sector that increase from the short run to the medium run, while both the 2.5 and 10\% VAT policy options will give rise to nearly the same positive percentage changes in the same sector's exports (Fig. 46). It is quite straightforward to understand why the $10 \%$ VAT policy will lead to an increase in exports as the VAT policy is associated with the highest depreciation of the national currency. Negative percentage changes will characterise utilities' exports under each of the VAT policy options with slightly reduced negative impact in the medium term (see Fig. 47). This can be explained by the fact that utilities' sector (incorporating water and electricity and related subsectors) sells more to the domestic market than to the foreign market.

Some positive percentage changes in services' exports will be forthcoming under the three VAT policy options during the 10-year period of simulations except the fact that the 5\% VAT policy option will engender negative percentage change in the first 2 years and the fact that declining positive trends will constitute the lots of impact of all of the VAT policy options in the medium term perhaps due to the mobility of capital across sectors in the medium term.

\section{Conclusion}

The study delves on the impact of three VAT policy options for Nigeria using a recursive dynamic computable general equilibrium model that is solved and simulated for 10 years. The 10-year period of solution/simulation incorporates a short-run period spanning the first 5 years and a medium run that covers the second 5 years. It is found that the $2.5 \%$ VAT policy option (that entails an increase of $2.5 \%$ on VAT rate per year in the next 4 years) will ensure the highest possible levels and positive percentage changes (over the base run) for real gross domestic product, investment, intermediate imports and government expenditure. Household consumption expenditure will register the 
least decline under the $2.5 \%$ VAT policy. Again, the $2.5 \%$ VAT policy option will result in the highest levels and positive percentage changes for government VAT revenue, tax revenue and total revenue in the medium term. While the $2.5 \%$ VAT policy results in the highest level and percentage change in total output produced in the economy, the impact of the policy is, however, not that of positive percentage change for every sector, and so, the impact is not uniform across sectors. The highest declines in exports $(1.74 \%)$ and final imports (2.98\%) over the 10-year period are nevertheless associated with the 2.5\% VAT policy, while exports and final imports will register the highest positive percentage changes of $2.27 \%$ and $5.27 \%$, respectively, under the $10 \%$ VAT policy option.

Given the centrality of exchange rate and wage rate dynamics in the nation's economy and in the household welfare, it is interesting and perhaps not surprising to find that the state of these two variables appears to dictate to a very large extent the results obtained with respect to household welfare. While the national currency, naira, depreciates by $1.85 \%$ under the $2.5 \%$ VAT policy, the $10 \%$ VAT policy option will depreciate the currency by $3.19 \%$ compared to $1.99 \%$ appreciation under the $5 \%$ VAT policy. On the other hand, wage rate (real) will decline by $3.55 \%$ under the $2.5 \%$ VAT policy, while it will fall by $6.65 \%$ under the $10 \%$ VAT policy option compared to $1.74 \%$ decrease under the $5 \%$ VAT policy option. The foregoing sort of provides some explanation for the second least decline observed in household welfare (N824.495 billion) as measured by equivalent variation under the 2.5\% VAT policy, while the highest decrease (N1280.353 billion) in the same socio-economic indicator will be associated with the $10 \%$ VAT policy option.

On the whole, it can be concluded that the $2.5 \%$ VAT policy option will deliver the best set of results/outcomes for the economy, households, firms and government. There will, however, be a need to address the welfare of the poor households that will be bruised in the process of implementing the policy. Income earning potentials of this set of households may need to be bolstered with part of the proceeds from the increase in VAT rate.

\section{List of variables}

PD: domestic price of commodity produced in the country; PE: price of commodity produced for export market; PM: price of final import in the domestic market; PN: price of intermediate import in the domestic market; P: price of composite commodity (final import and domestic supply); PV: value-added price; PK: rental rate of capital (price of capital); W: wage rate; PINDEX: price index; PWE: world price of export; PWM: world price of final import; PWN: world price of intermediate import; ER: exchange rate of naira against foreign currency; N: quantity of intermediate import; M: quantity of final import; D: supply of commodity into domestic market by domestic producers; E: quantity of export commodity; Q: quantity of composite commodity (final import and domestic supply); X: quantity of gross output; INT: quantity of domestic intermediate; INTD: supply of intermediate; XV: quantity of value-added; LAB: demand for labour; CAP: demand for capital; L: supply of labour; K: supply of capital; CAPY: gross capital income; LABY: gross labour income; DEP: total depreciation; HHDIV: dividend for households; HHDITOT: total dividend for households; RETEARN: retained earnings; RETEARNTOT: total retained earnings; ROWDIV: dividend for rest of the world; ROWDVITOT: total dividend for rest of the world; $\mathrm{HHDIVY}_{H}$ : dividend for household $\mathrm{H}_{;} \mathrm{HHLABY}_{H}$ : labour income due to household $\mathrm{H}_{;} \mathrm{HHYTOT}_{H}$ : total income due to household $\mathrm{H} ; \mathrm{HCONS}_{H, \text { : }}$ matrix of households' consumption of commodities; TOTHCONS ${ }_{H}$ : total consumption of household H across commodities; UTILITY : utility of household H; UTILITOT: total utility of households; SUBSIDY: subsidy across commodities; VAT: value-added tax revenue; IMTAX: import duties' revenue; PPTREV: petroleum profit tax revenue; EXTAX: excise duties' revenue; OILDOMREV: domestic oil sales revenue; OILFORREV: foreign oil sales revenue; COYTAX: company income tax revenue by commodity/sector; COYTAXTOT: total company income tax revenue; GRTOT: total government revenue (less subsidy); GETOT: total government expenditure; SECGOV: sectoral government expenditure; GOVSAV: government savings; $\mathrm{HSAV}_{\mathrm{H}}$ : savings of household H; FSAV: foreign savings; WALRAS: variable for testing optimality of solution, expected to be zero; SAVINGS: national savings; ID: investment demand by sector; INVEST: total investment; RGDP: real gross domestic product. 


\section{List of parameters}

TA: excise duties and value-added tax rates; IO: input-output coefficients (matrix); NX: intermediate import per unit of output; PWTS: composite commodity weights; TE: export duties'rate (remains at zero since 1991); TM: import duties' rate on final import; TN: import duties' rate on intermediate import; TVM: value-added tax rate on final import; TVN: value-added tax rate on intermediate import; SCX: shift parameter of constant elasticity of substitution (CES) production function for gross output; ASX: share parameter of CES function for gross output; CESX: elasticity parameter of CES function for gross output; SC: shift parameter of CES function for value-added output; AS: share parameter of CES function for value-added output; CESV: elasticity parameter of CES function for value-added output; AT: shift parameter of constant elasticity of transformation (CET) function; BETA: share parameter of CET function; RHOT: elasticity parameter of CET function; AC: shift parameter of CES function for consumption of composite commodity; DELTA: share parameter of CES function for consumption of composite commodity; RHOC: elasticity parameter of CES function for consumption of composite commodity; V: value-added per unit of gross output; NT: domestic intermediate per unit of gross output; DEPR: depreciation rate; HHDR: dividend rate for households; PPT: petroleum profit rate; RETER: retained earnings rate; ROWDR: dividend rate for rest of the world; HKYSHAR: rates of share of dividend across sectors for households; HLYSHAR: rates of share of labour income across sectors for households; HEXPS: expenditure shares of households across sectors; SUB: subsidy rate; OILDOMR: share of oil output sold domestically; OILFORR: share of oil output sold to rest of the world; COYTR: company income tax rate; GSEC: shares of government expenditure across sectors; GOVSAVR: savings rate of government; PGR: population growth rate; OGR: growth rate of oil revenue.

\section{Acknowledgements}

Not applicable.

\section{Authors' contributions}

Every section of the study was researched and written by the author.

\section{Authors' information}

The author lectures at university level and specialises in public-sector economics, microeconomics, macroeconomics, labour economics and applied general equilibrium modelling.

\section{Funding}

Not applicable.

\section{Availability of data and materials}

Part of the main sources of data for the study is Input-Output Table of Nigeria for the 2011 fiscal year (which starts on 1 January and ends on 31 December). The Input-Output Table was obtained from the National Institute of Social and Economic Research (NISER), Ibadan, Nigeria. Another part of the study's data was derived from the poverty profile of Nigeria for 2010. The poverty profile was compiled/published by the National Bureau of Statistics, Abuja, Nigeria. The data on taxes and their rates were obtained from the Tariff and Excise Schedule and fiscal revenue across different taxes as at 2011.

\section{Competing interest}

Not applicable. There are no competing interests whatsoever.

\section{Appendix: List of model's equations}

See Tables 1, 2, 3, 4, 5 and Figs. 2, 3, 4, 5, 6, 7, 8, 9, 10, 11, 12, 13, 14, 15, 16, 17, 18, 19, 20, 21, $22,23,24,25,26,27,28,29,30,31,32,33,34,35,36,37,38,39,40,41,42,43,44,45,46,47,48$.

Table 1 Percentage changes in government revenue over the base run across periods Source: Model simulations

\begin{tabular}{lllc}
\hline Revenue type & VAT policy (\%) & First 5 years (\%) & $\begin{array}{l}\text { Second five } \\
\text { years (\%) }\end{array}$ \\
\hline VAT revenue & 2.5 & 139.64 & 202.42 \\
& 5 & 136.34 & 199.65 \\
Total tax revenue & 10 & 196.63 & 201.41 \\
& 2.5 & 18.22 & 32.98 \\
Total government revenue & 5 & 18.84 & 31.20 \\
& 10 & 23.26 & 32.66 \\
& 2.5 & 11.84 & 22.03 \\
& 5 & 10.67 & 19.38 \\
\hline
\end{tabular}


Table 2 Impact of value-added tax policy on macro-variables (percentage changes over base run) Source: Model simulations

\begin{tabular}{llllllll}
\hline $\begin{array}{l}\text { Value- } \\
\text { added } \\
\text { tax policy } \\
\text { option (\%) }\end{array}$ & $\begin{array}{l}\text { Extra } \\
\text { output } \\
\text { growth } \\
(\%)\end{array}$ & $\begin{array}{l}\text { Final } \\
\text { imports (\%) }\end{array}$ & $\begin{array}{l}\text { Intermediate } \\
\text { imports (\%) }\end{array}$ & $\begin{array}{l}\text { Exports } \\
\text { (\%) }\end{array}$ & $\begin{array}{l}\text { Investment } \\
(\%)\end{array}$ & $\begin{array}{l}\text { Government } \\
\text { expenditure } \\
(\%)\end{array}$ & $\begin{array}{l}\text { Household } \\
\text { consumption } \\
\text { (\%) }\end{array}$ \\
\hline 2.5 & 0.24 & -2.98 & 2.08 & -1.74 & 4.83 & 16.47 & -2.51 \\
5 & 0.19 & 0.56 & 0.94 & -0.10 & 2.75 & 14.75 & -6.96 \\
10 & 0.16 & 5.27 & -1.43 & 2.27 & -3.15 & 13.04 & -14.38 \\
\hline
\end{tabular}

Table 3 Incidence of value-added tax policy options. Source: Model simulations

\begin{tabular}{|c|c|c|c|c|}
\hline Households & $\begin{array}{l}\text { Income level } \\
\text { (highest } \\
\text { to lowest) }\end{array}$ & $\begin{array}{l}\text { Equivalent variation } \\
\text { as percentage } \\
\text { of income under } 2.5 \% \\
\text { VAT policy }\end{array}$ & $\begin{array}{l}\text { Equivalent variation } \\
\text { as percentage } \\
\text { of income under } 5 \% \\
\text { VAT policy }\end{array}$ & $\begin{array}{l}\text { Equivalent variation } \\
\text { as percentage } \\
\text { of income under } 10 \% \\
\text { VAT policy }\end{array}$ \\
\hline Rural non-poor & 1 & -2.69 & -1.85 & -4.37 \\
\hline Urban non-poor & 2 & -5.82 & -5.84 & -10.55 \\
\hline $\begin{array}{l}\text { Rural moderately } \\
\text { poor }\end{array}$ & 3 & -4.49 & -0.33 & -7.33 \\
\hline $\begin{array}{l}\text { Urban moderately } \\
\text { poor }\end{array}$ & 4 & -0.30 & -1.40 & -2.11 \\
\hline Rural poor & 5 & -3.45 & -2.38 & -4.69 \\
\hline Urban poor & 6 & -2.82 & -0.92 & -4.61 \\
\hline
\end{tabular}

Table 4 Percentage changes in exchange rate and wage rate. Source: Model simulation

\begin{tabular}{lcc}
\hline VAT policy (\%) & Exchange rate (\%) & Wage rate (\%) \\
\hline 2.5 & 1.85 & -3.55 \\
5 & -1.99 & -1.74 \\
10 & 3.19 & -6.65 \\
\hline
\end{tabular}

Table 5 Percentage change in sectoral output

\begin{tabular}{ll}
\hline VAT policy (\%) & Change in sectoral output (\%) \\
\hline 2.5 & 2.41 \\
5 & 0.95 \\
10 & 1.79 \\
\hline
\end{tabular}

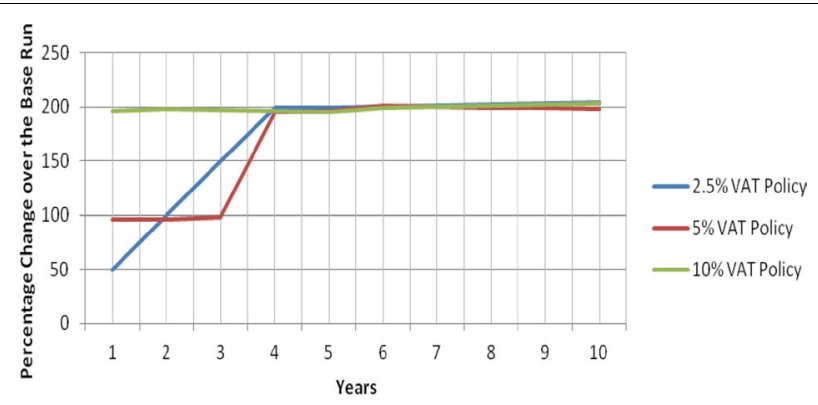

Fig. 2 Impact of VAT policy on VAT revenue 


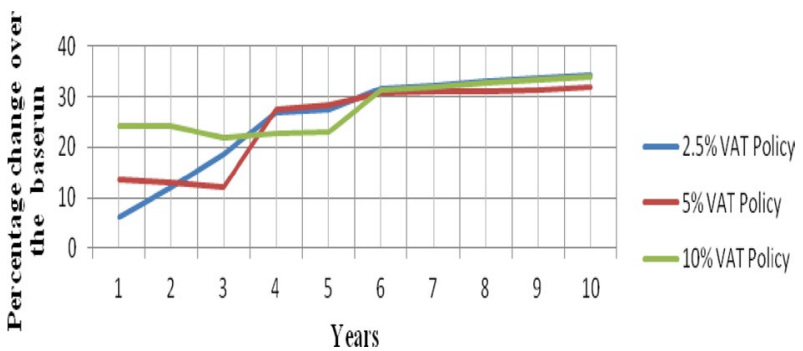

Fig. 3 Impact of VAT policy on total tax revenue

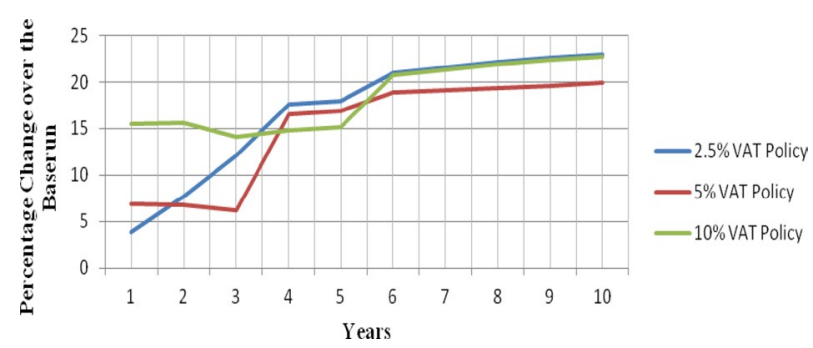

Fig. 4 Impact of VAT policy on total government revenue

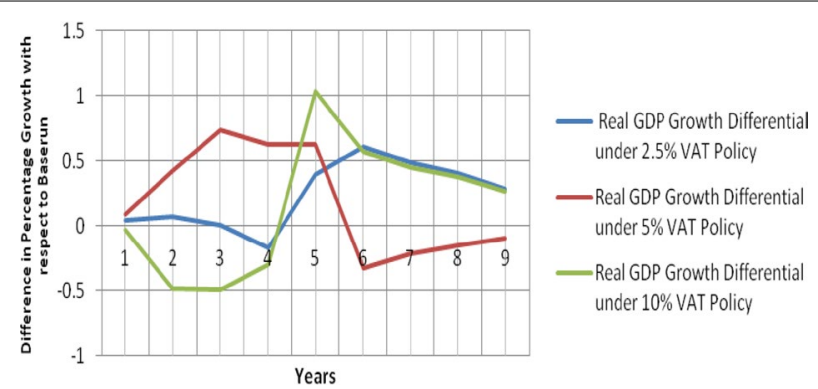

Fig. 5 Impact of VAT policy on real GDP growth differential

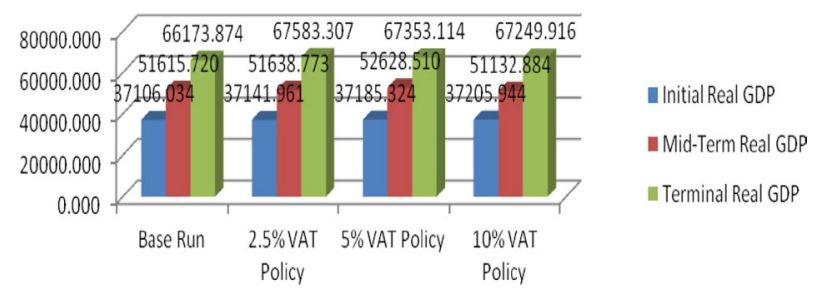

Fig. 6 Trends in real gross domestic product (billion Naira) 


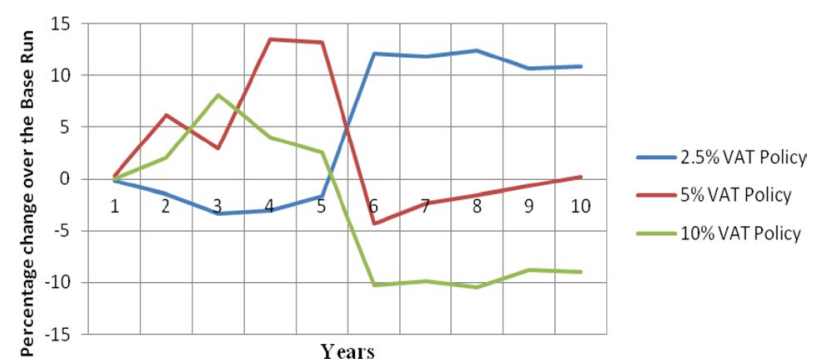

Fig. 7 Total investment

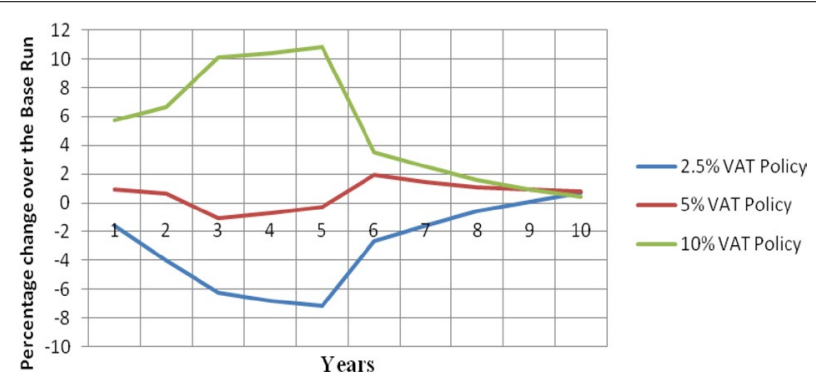

Fig. 8 Total final import

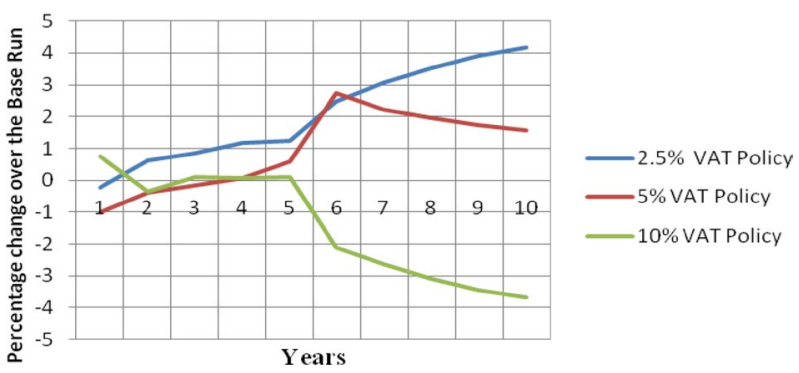

Fig. 9 Total intermediate import

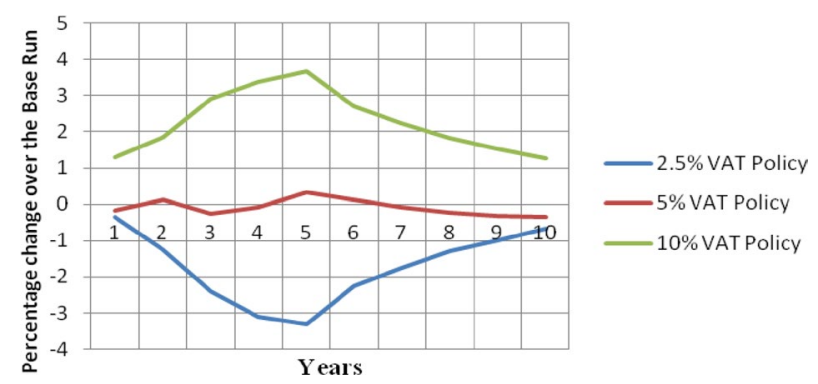

Fig. 10 Total export 


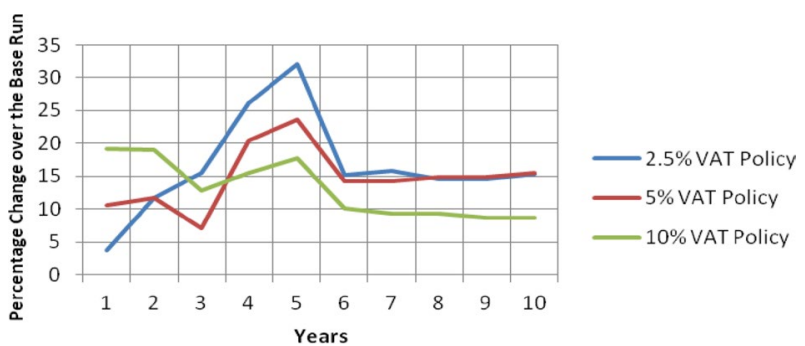

Fig. 11 Percentage changes in government real expenditure

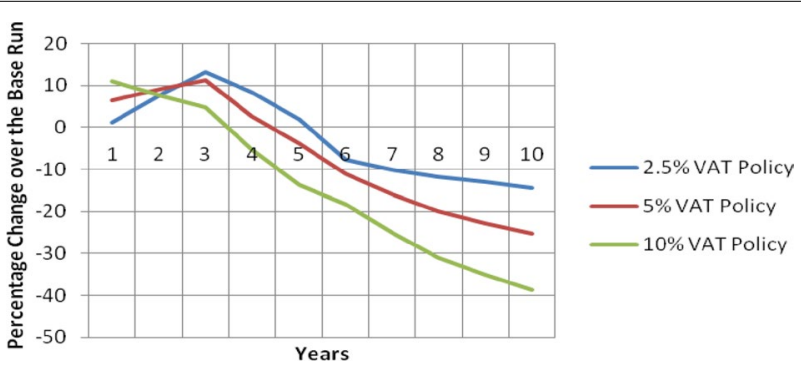

Fig. 12 Percentage changes in household real expenditure

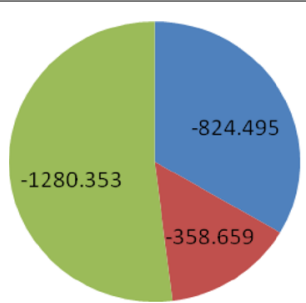

$$
\begin{aligned}
& \text { Equivalent Variation } \\
& \text { under 2.5 Percent VAT } \\
& \text { Policy } \\
& \text { Equivalent Variation } \\
& \text { under } 5 \text { Percent VAT } \\
& \text { Policy } \\
& \text { Equivalent Variation } \\
& \text { under } 10 \text { Percent VAT } \\
& \text { Policy }
\end{aligned}
$$

Fig. 13 Equivalent variation across household over the 10-year period

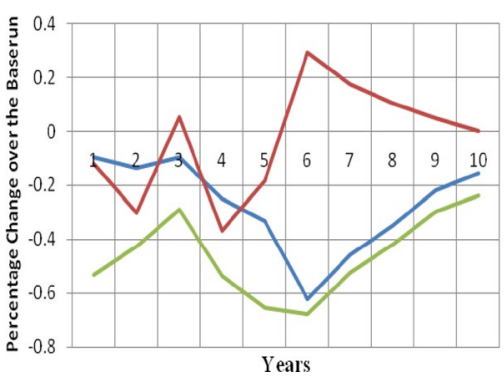

- Households Welfare under 5\% VATPolicy

- Households Welfare under $2.5 \%$ VAT Policy

- Households Welfare under $10 \%$ VAT Policy

Fig. 14 Percentage change in households' welfare 


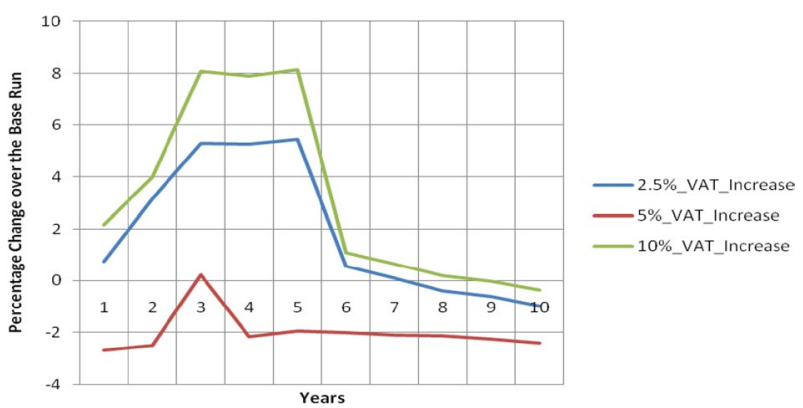

Fig. 15 Exchange rate movement

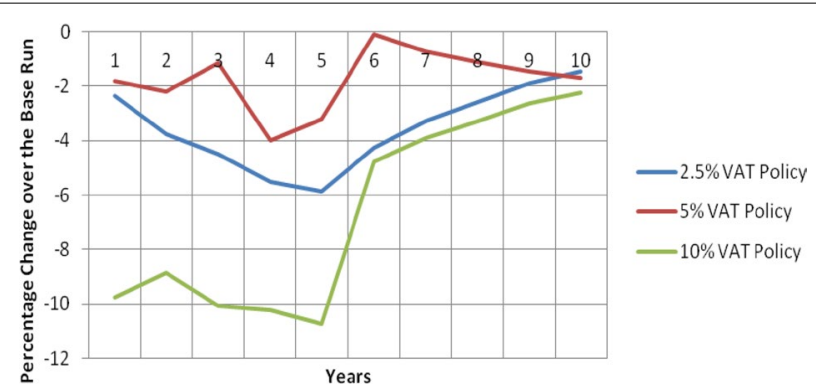

Fig. 16 Wage rate movement

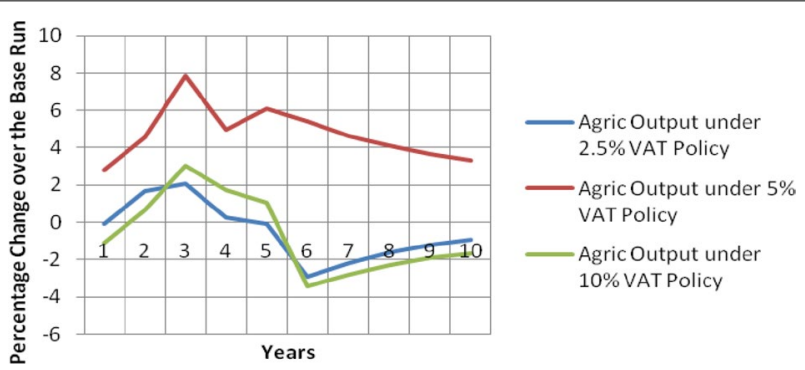

Fig. 17 Impact of different VAT policies on agricultural output

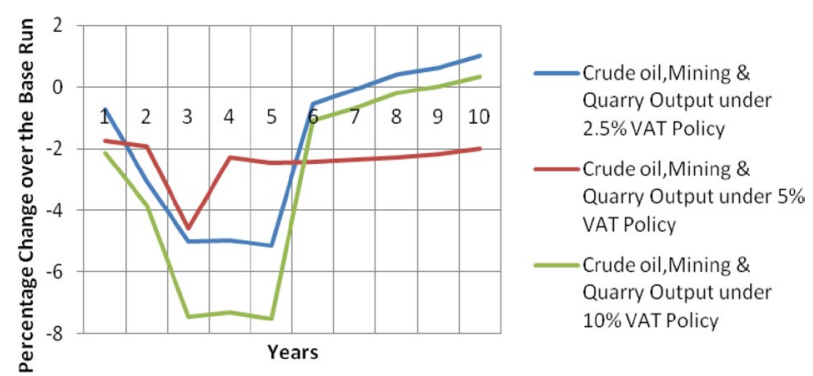

Fig. 18 Impact of different VAT policies on crude oil, mining and quarry output 

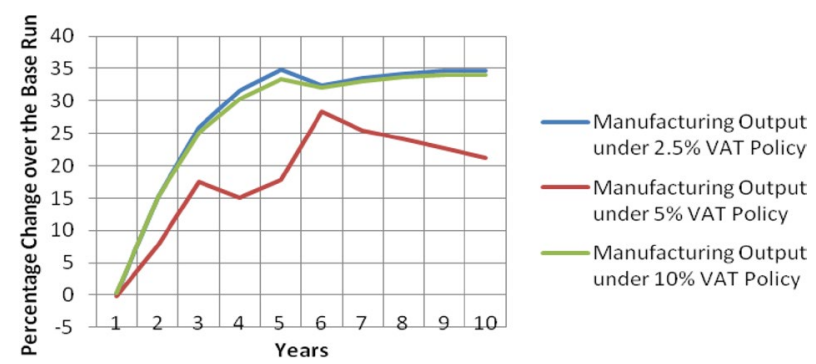

Fig. 19 Impact of different VAT policies on manufacturing output

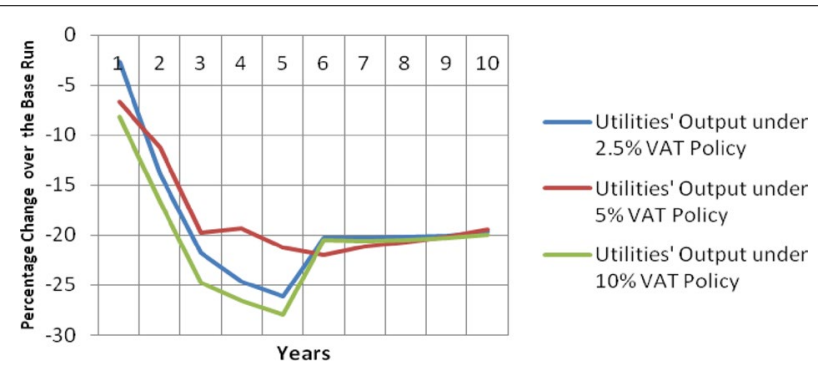

Fig. 20 Impact of different VAT policies on utilities' output

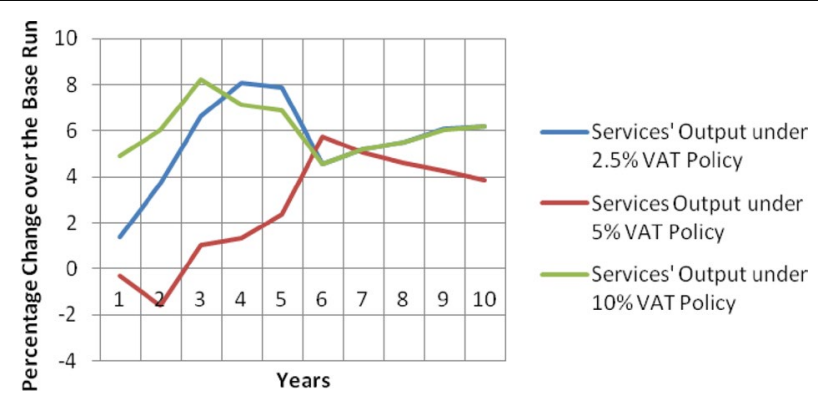

Fig. 21 Impact of different VAT policies on services' output

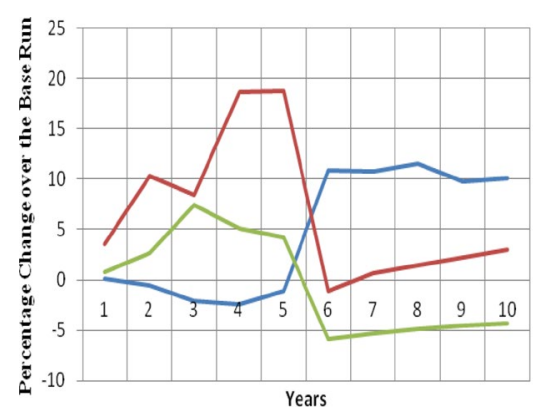

- Agriculture Investment under $2.5 \%$ VAT Policy

- Agriculture Investment under 5\%VAT Policy

- Agriculture Investment under $10 \%$ VAT Policy

Fig. 22 Changes in agriculture investment under varying VAT rates 


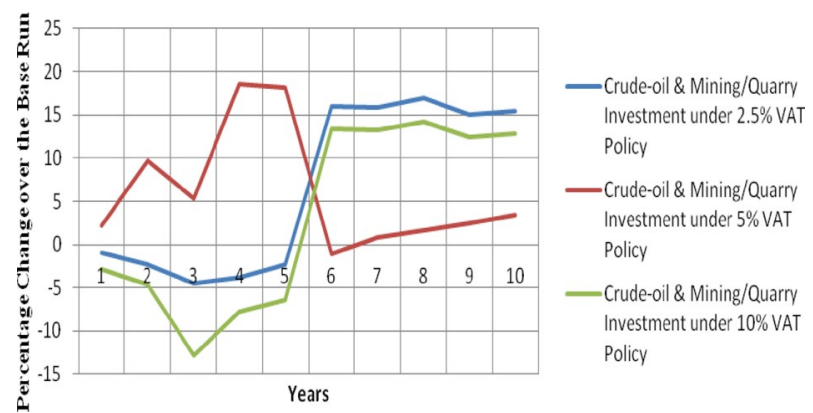

Fig. 23 Changes in crude oil and mining/quarry investment under varying VAT rates

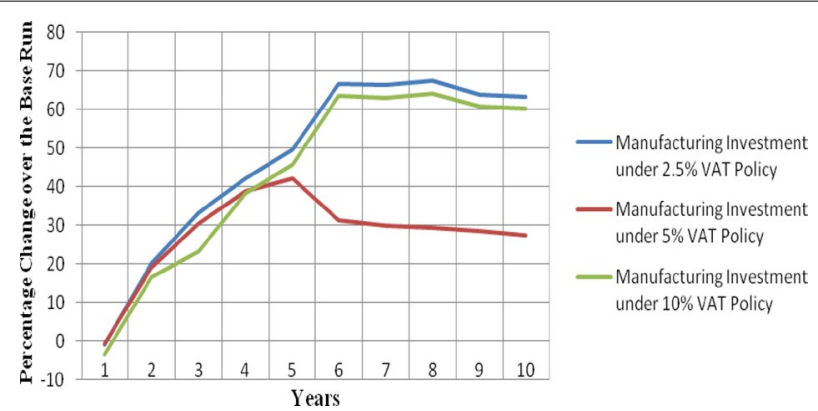

Fig. 24 Changes in manufacturing investment under varying VAT rates

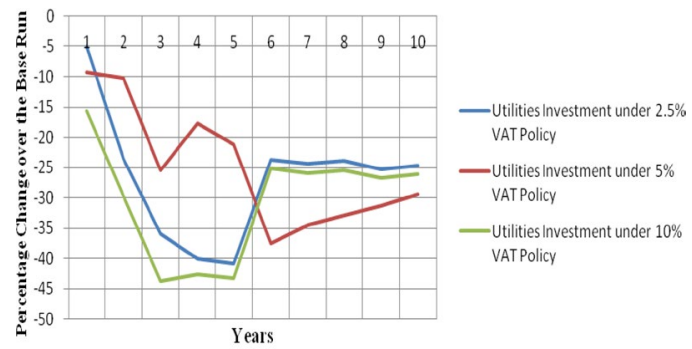

Fig. 25 Changes in utilities investment under varying VAT rates

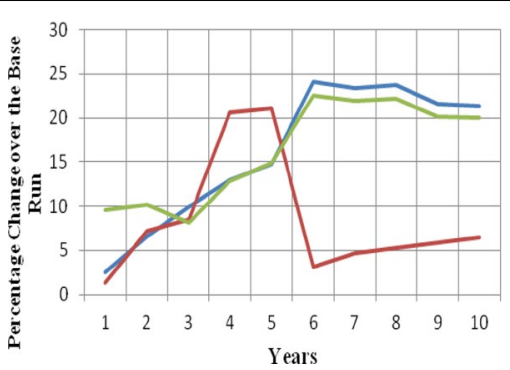

- Services Investment under 2.5\% VAT Policy

- Services Investment under 5\% VAT Policy

Services Investment under 10\% VAT Policy

Fig. 26 Changes in services investment under varying VAT rates 


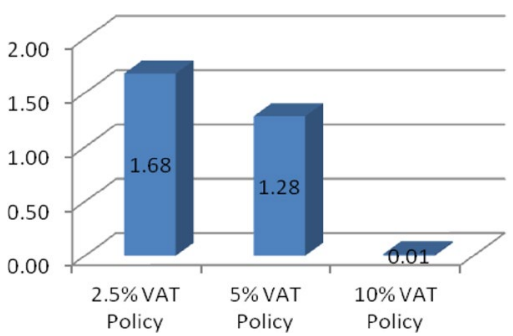

Average Growth in

Capital Stock over

Baserun across Sectors

Fig. 27 Average growth in capital stock over base run across sectors

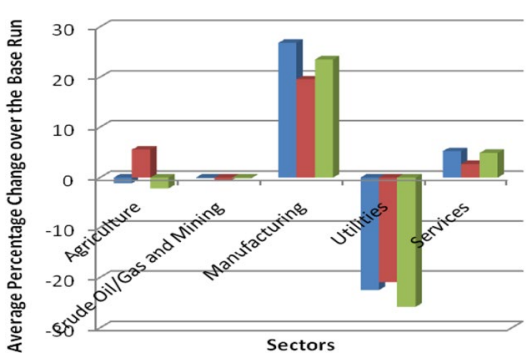

= $2.5 \%$ VAT Rate Increase

$5 \%$ VAT Rate Increase

$10 \%$ VAT Rate Increase

Fig. 28 Percentage change in capital stock over the ten-year period

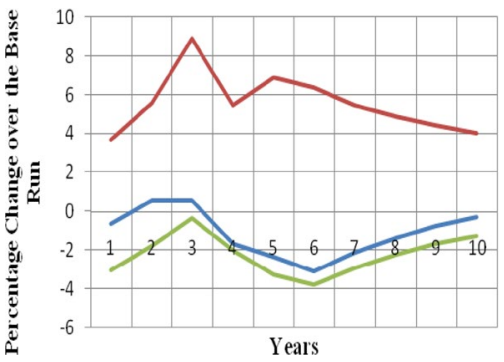

- $2.5 \%$ VAT Effects on Agricultural Sector Capital

- $5 \%$ VAT Effects on Agricultural Sector Capital

$10 \%$ VAT Effects on Agricultural Sector Capital

Fig. 29 Changes in capital stock in agriculture

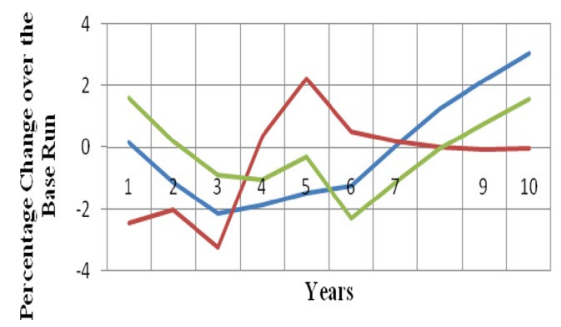

2.5\% VAT Effects on Crude Oil/Gasand Mining Capital

$5 \%$ VAT Effects on Crude Oil/Gasand Mining Capital

- $10 \%$ VAT Effects on Crude Oil/Gas and Mining Capital

Fig. 30 Changes in capital stock in crude oil/gas and mining 


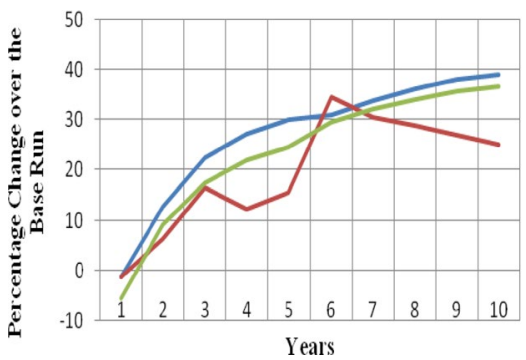

$-2.5 \%$ VAT Effects on Manufacturing Sector Capital

- $5 \%$ VAT Effects on Manufacturing Sector Capital

- $10 \%$ VAT Effects on Manufacturing Sector Capital

Fig. 31 Changes in capital stock in manufacturing

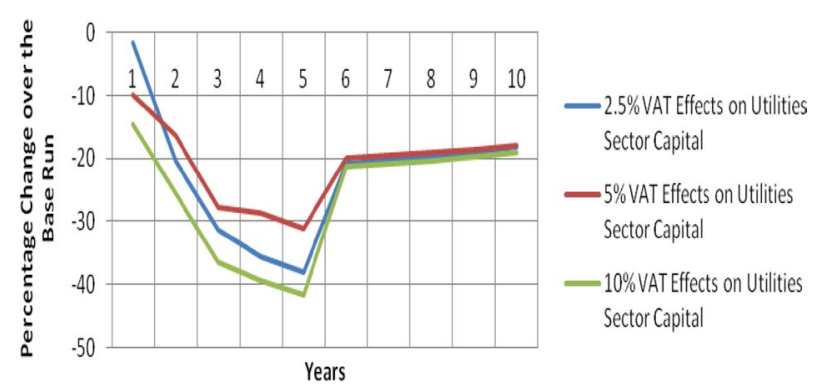

Fig. 32 Changes in capital stock in utilities

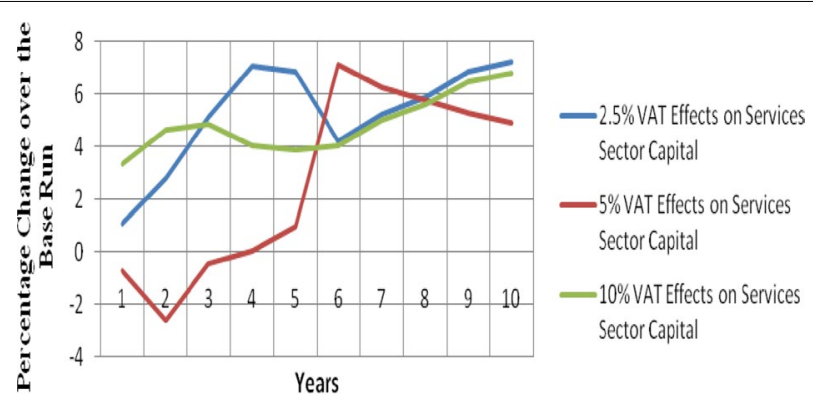

Fig. 33 Changes in capital stock in services sector

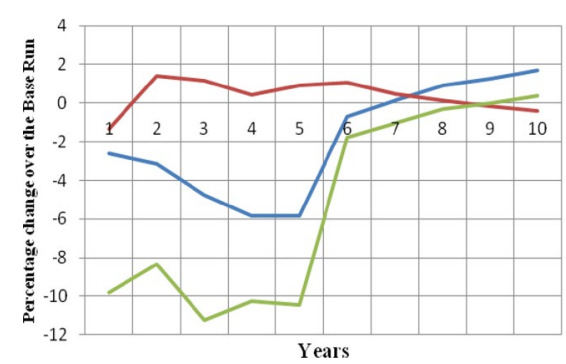

-Agriculture Final Import under $2.5 \%$ VAT Policy

-Agriculture Final Import under 5\% VAT Policy

— Agriculture Final Import under $10 \%$ VAT Policy

Fig. 34 Changes in agricultural final imports under varying VAT rates 


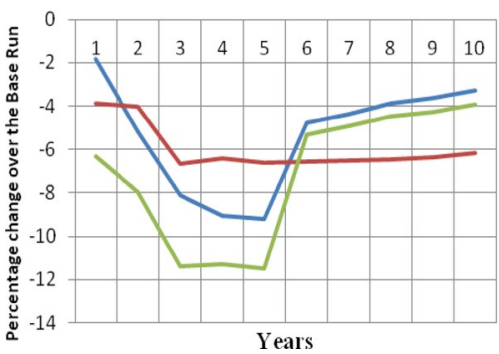

Crude-oil \& Mining/Quarry Final Import under $2.5 \%$

VAT Policy

Crude-oil \& Mining/Quarry

Final Import under $5 \%$ VAT

Policy

Crude-oil \& Mining/Quarry Final Import under $10 \%$

VAT Policy

Fig. 35 Changes in crude oil/gas and mining/quarry final imports under varying VAT rates

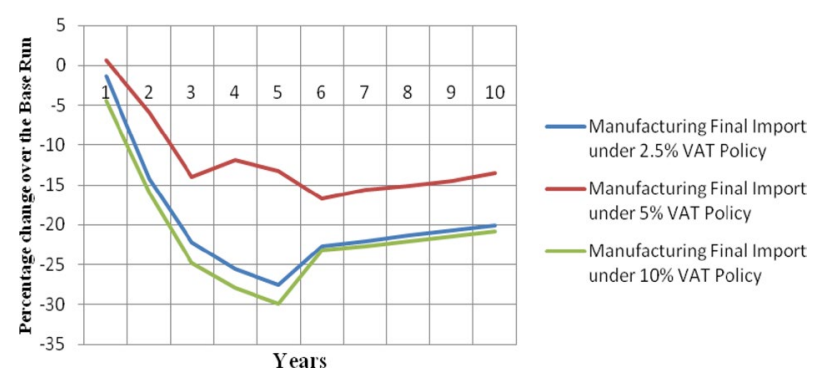

Fig. 36 Changes in manufacturing final imports under varying VAT rates

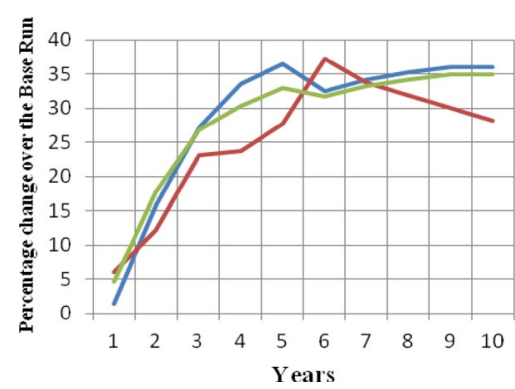

Utilities Final Import under $2.5 \%$ VAT Policy

Utilities Final Import under 5\% VAT Policy

Utilities Final Import under $10 \%$ VAT Policy

Fig. 37 Changes in utilities final imports under varying VAT rates

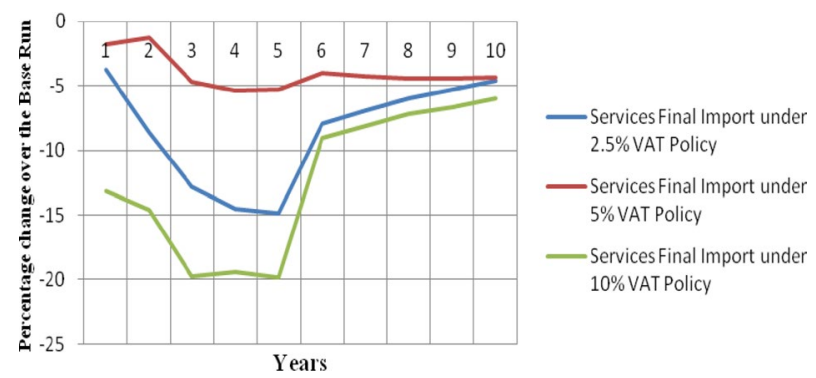

Fig. 38 Changes in services final imports under varying VAT rates 


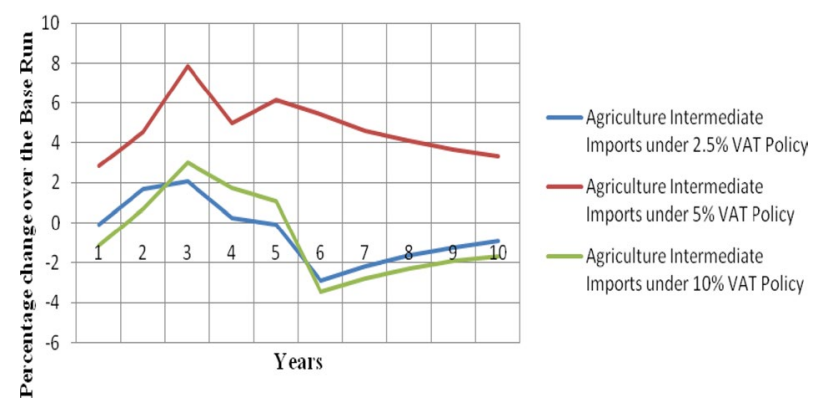

Fig. 39 Changes in agricultural intermediate imports under varying VAT rates

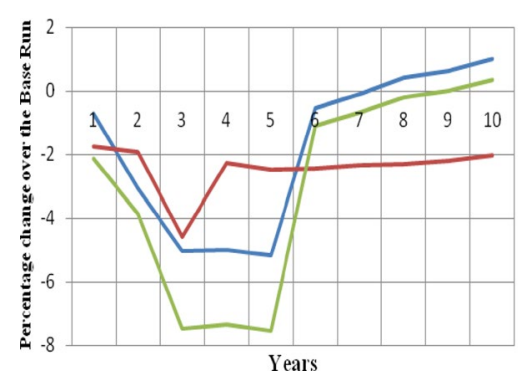

$$
\begin{aligned}
& \text { —Crude-oil \& Mining/Quarry } \\
& \text { Intermediate Imports under } \\
& 2.5 \% \text { VAT Policy } \\
& \text { — Crude-oil \& Mining/Quarry } \\
& \text { Intermediate Imports under 5\% } \\
& \text { VAT Policy } \\
& \text { —Crude-oil \& Mining/Quarry } \\
& \text { Intermediate Imports under } \\
& \text { 10\%VAT Policy }
\end{aligned}
$$

Fig. 40 Changes in crude oil/gas and mining/quarry intermediate imports under varying VAT rates

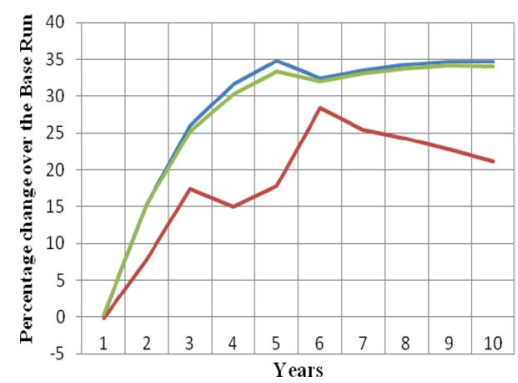

- Manufacturing Intermediate Imports under $2.5 \%$ VAT Policy

-Manufacturing Intermediate Imports under 5\% VAT Policy

- Manufacturing Intermediate Imports under $10 \%$ VAT Policy

Fig. 41 Changes in manufacturing intermediate imports under varying VAT rates

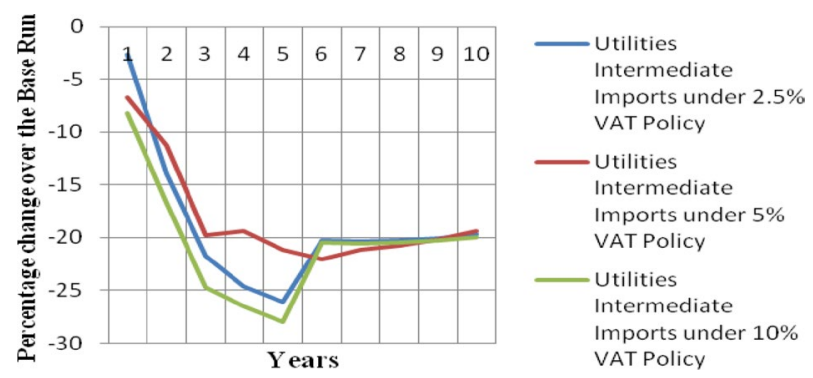

Fig. 42 Changes in utilities' intermediate imports under varying VAT rates 

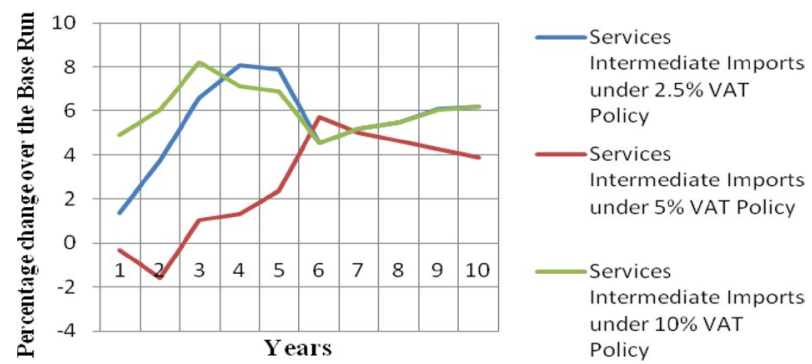

Fig. 43 Changes in services intermediate imports under varying VAT rates

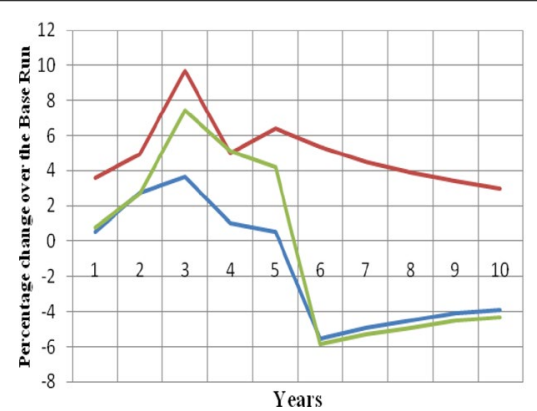

- Agriculture Export under 2.5\% VATPolicy

- Agriculture Export under 5\% VAT Policy

- Agriculture Export under 10\% VATPolicy

Fig. 44 Changes in agricultural exports under varying VAT rates

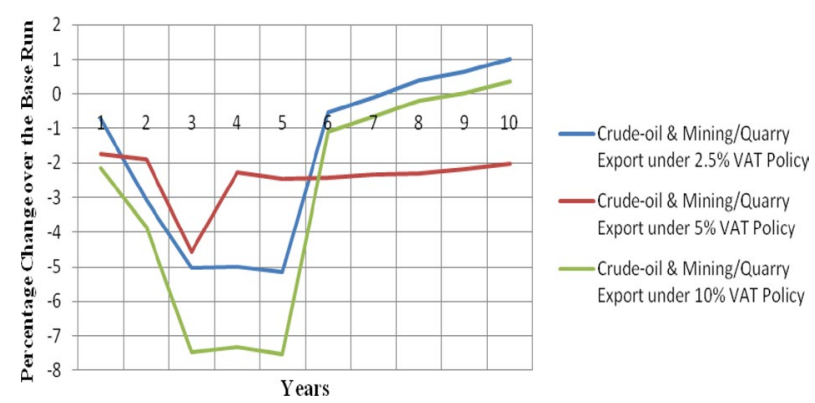

Fig. 45 Changes in crude oil/gas and mining/quarry exports under varying VAT rates

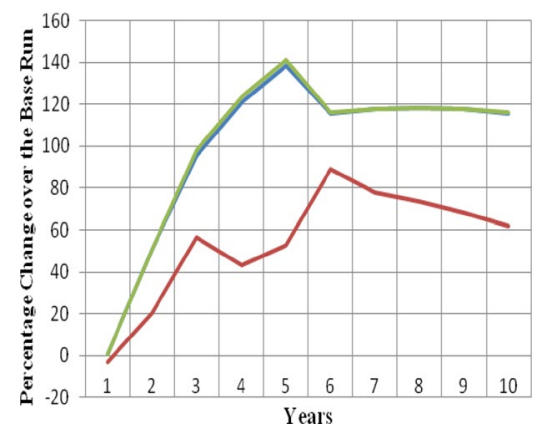

Manufacturing Exports under $2.5 \%$ VAT Policy

-Manufacturing Exports under $5 \%$ VAT Policy

Manufacturing Exports under $10 \%$ VAT Policy

Fig. 46 Changes in manufacturing exports under varying VAT rates 


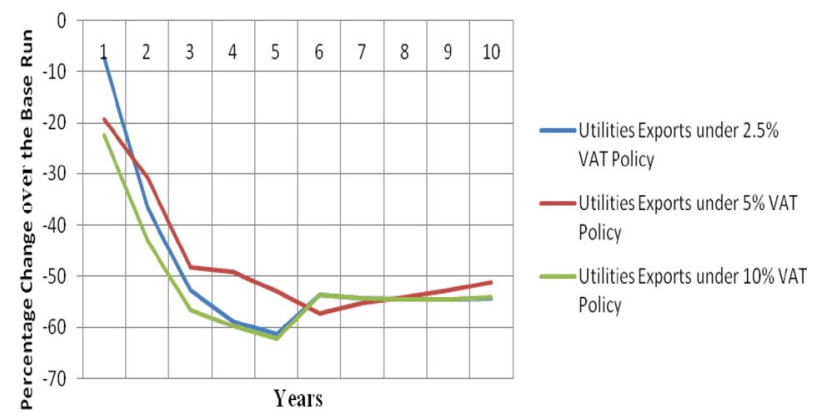

Fig. 47 Changes in utilities exports under varying VAT rates

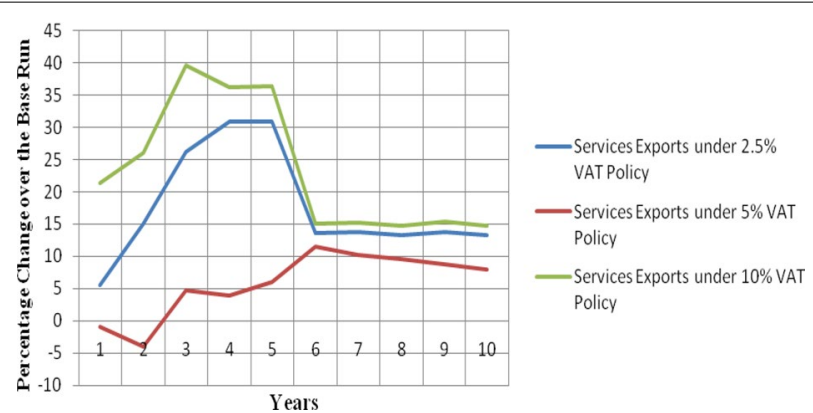

Fig. 48 Changes in services exports under varying VAT rates

Price block

$\mathrm{PV}_{\mathrm{I}}=\mathrm{PX}_{\mathrm{I}} *\left(1-\mathrm{TA}_{\mathrm{I}}\right)-\sum_{\mathrm{J}} \mathrm{IO}_{\mathrm{I}, \mathrm{J}} * \mathrm{P}_{\mathrm{J}}-\mathrm{PN}_{\mathrm{I}} * \mathrm{NX}_{\mathrm{I}}$

$\mathrm{PINDEX}=\sum_{\mathrm{I}}\left(\mathrm{PWTS}_{\mathrm{I}} * \mathrm{P}_{\mathrm{I}}\right)$

$\mathrm{PE}_{\mathrm{I}}=\mathrm{PWE}_{\mathrm{I}} *\left(1+\mathrm{TE}_{\mathrm{I}}\right) * \mathrm{ER}$

$\mathrm{PM}_{\mathrm{I}}=\mathrm{PWM}_{\mathrm{I}} *\left(1+\mathrm{TM}_{\mathrm{I}}\right) *\left(1+\mathrm{TVM}_{\mathrm{I}}\right) * \mathrm{ER}$

$\mathrm{PN}_{\mathrm{I}}=\mathrm{PWN}_{\mathrm{I}} *\left(1+\mathrm{TN}_{\mathrm{I}}\right) *\left(1+\mathrm{TVN}_{\mathrm{I}}\right) * \mathrm{ER}$

$P_{\mathrm{I}} * Q_{\mathrm{I}}=\mathrm{PD}_{\mathrm{I}} * D_{\mathrm{I}}+\mathrm{PM}_{\mathrm{I}} * M_{\mathrm{I}}$

$\mathrm{PX}_{\mathrm{I}} * \mathrm{X}_{\mathrm{I}}=\mathrm{PD}_{\mathrm{I}} * D_{\mathrm{I}}+\mathrm{PE}_{\mathrm{I}} * E_{\mathrm{I}}$

Production and trade block

$$
\begin{aligned}
& X_{\mathrm{I}}=\mathrm{SCX}_{\mathrm{I}} *\left(\mathrm{ASX}_{\mathrm{I}} * \mathrm{INT}_{\mathrm{I}} * *\left(-\mathrm{CESX}_{\mathrm{I}}\right)+\left(1-\mathrm{ASX}_{\mathrm{I}}\right) * \mathrm{XV}_{\mathrm{I}} * *\left(-\mathrm{CESX}_{\mathrm{I}}\right)\right) *\left(-1 / \mathrm{CESX}_{\mathrm{I}}\right) \\
& \mathrm{XV}_{\mathrm{I}}=\mathrm{SC}_{\mathrm{I}} *\left(\mathrm{AS}_{\mathrm{I}} * \mathrm{LAB}_{\mathrm{I}} * *\left(-\mathrm{CESV}_{\mathrm{I}}\right)+\left(1-\mathrm{AS}_{\mathrm{I}}\right) * \mathrm{CAP}_{\mathrm{I}} * *\left(-\mathrm{CESV}_{\mathrm{I}}\right)\right) *\left(-1 / \mathrm{CESV}_{\mathrm{I}}\right)
\end{aligned}
$$


$\mathrm{LAB}_{\mathrm{I}} / \mathrm{CAP}_{\mathrm{I}}=\left(\mathrm{AS}_{\mathrm{I}} /\left(1-\mathrm{AS}_{\mathrm{I}}\right) * *\left(1 /\left(1+\mathrm{CESV}_{\mathrm{I}}\right) *\left(\mathrm{PK}_{\mathrm{I}} / W\right) * *\left(1 /\left(1+\mathrm{CESV}_{\mathrm{I}}\right)\right)\right.\right.$

$X_{\mathrm{I}}=\mathrm{AT}_{\mathrm{I}} *\left(\mathrm{BETA}_{\mathrm{I}} * E_{\mathrm{I}} * * \mathrm{RHOT}_{\mathrm{I}}+\left(1-\mathrm{BETA}_{\mathrm{I}}\right) * D_{\mathrm{I}} * * \mathrm{RHOT}_{\mathrm{I}}\right) * *\left(1 / \mathrm{RHOT}_{\mathrm{I}}\right)$

$D_{\mathrm{I}} / E_{\mathrm{I}}=\left(\left(\mathrm{PD}_{\mathrm{I}} / \mathrm{PE}_{\mathrm{I}}\right) *\left(\mathrm{BETA}_{\mathrm{I}} /\left(1-\mathrm{BETA}_{\mathrm{I}}\right)\right)\right) * *\left(1 /\left(\mathrm{RHOT}_{\mathrm{I}}-1\right)\right)$

$Q_{\mathrm{I}}=\mathrm{AC}_{\mathrm{I}} *\left(\left(\mathrm{DELTA}_{\mathrm{I}} * M_{\mathrm{I}} * *\left(-\mathrm{RHOC}_{\mathrm{I}}\right)\right.\right.$ $\left.+\left(1-\mathrm{DELTA}_{\mathrm{I}}\right) * D_{\mathrm{I}} * *\left(-\mathrm{RHOC}_{\mathrm{I}}\right)\right) * *\left(-1 / \mathrm{RHOC}_{\mathrm{I}}\right)$

$N_{\mathrm{I}}=\mathrm{NX}_{\mathrm{I}} * X_{\mathrm{I}}$

$\mathrm{XV}_{\mathrm{I}}=V_{\mathrm{I}} * X_{\mathrm{I}}$

$\mathrm{INT}_{\mathrm{I}}=\mathrm{NT}_{\mathrm{I}} * X_{\mathrm{I}}$

$D_{\mathrm{I}} / M_{\mathrm{I}}=\left(\left(\mathrm{PM}_{\mathrm{I}} / \mathrm{PD}_{\mathrm{I}}\right) *\left(\left(1-\mathrm{DELTA}_{\mathrm{I}}\right) / \mathrm{DELTA}_{\mathrm{I}}\right)\right) * *\left(1 /\left(\mathrm{RHOC}_{\mathrm{I}}+1\right)\right)$

Institutional block

$\mathrm{CAPY}=\sum_{\mathrm{I}}\left(\mathrm{CAP}_{\mathrm{I}} * \mathrm{PK}_{\mathrm{I}}\right)$

$\mathrm{DEP}=\sum_{\mathrm{I}}\left(\mathrm{CAP}_{\mathrm{I}} * \mathrm{PK}_{\mathrm{I}} * \mathrm{DEPR}_{\mathrm{I}}\right)$

$\mathrm{LABY}=\sum_{\mathrm{I}} \mathrm{LAB}_{\mathrm{I}} * W$

$\mathrm{HHDIV}_{\mathrm{I}}=\mathrm{HHDR}_{\mathrm{I}} * \mathrm{PK}_{\mathrm{I}} * \mathrm{CAP}_{\mathrm{I}} *\left(1-\mathrm{DEPR}_{\mathrm{I}}-\mathrm{PPT}_{\mathrm{I}}\right)$

$\mathrm{HHDIVTOT}=\sum_{\mathrm{I}} \mathrm{HHDIV}_{\mathrm{I}}$

RETEARN $_{\mathrm{I}}=$ RETER $_{\mathrm{I}} * \mathrm{PK}_{\mathrm{I}} * \mathrm{CAP}_{\mathrm{I}} *\left(1-\mathrm{DEPR}_{\mathrm{I}}-\mathrm{PPT}_{\mathrm{I}}\right)$

RETEARNTOT $=\sum_{\mathrm{I}}$ RETEARN $_{\mathrm{I}}$

ROWDIV $_{\mathrm{I}}=\mathrm{ROWDR}_{\mathrm{I}} * \mathrm{PK}_{\mathrm{I}} * \mathrm{CAP}_{\mathrm{I}} *\left(1-\mathrm{DEPR}_{\mathrm{I}}-\mathrm{PPT}_{\mathrm{I}}\right)$

ROWDIVTOT $=\sum_{\mathrm{I}}$ ROWDIV $_{\mathrm{I}}$

$\operatorname{HHDIVY}_{\mathrm{H}}=\sum_{\mathrm{I}}\left(\mathrm{HKYSHAR}_{\mathrm{H}, \mathrm{I}} * \mathrm{HHDIV}_{\mathrm{I}}\right)$

$\mathrm{HHLABY}_{\mathrm{H}}=\sum_{I}\left(\mathrm{HLYSHAR}_{\mathrm{H}, \mathrm{I}} * W * \mathrm{LAB}_{\mathrm{I}}\right)$ 


$$
\begin{aligned}
& \mathrm{HHYTOT}_{\mathrm{H}}=\mathrm{HHDIVY}_{\mathrm{H}}+\mathrm{HHLABY}_{\mathrm{H}} \\
& \mathrm{HCONS}_{\mathrm{HI}}=\operatorname{HEXPS}_{\mathrm{H}, \mathrm{I}} *\left(\mathrm{HHYTOT}_{\mathrm{H}} / \mathrm{P}_{\mathrm{I}}\right) \\
& \text { TOTHCONS }_{\mathrm{H}}=\sum_{\mathrm{I}} \mathrm{HCONS}_{\mathrm{H}, \mathrm{I}} \\
& \text { UTILITY }_{\mathrm{H}}=\sum_{\mathrm{I}}\left(\mathrm{HEXPS}_{\mathrm{H}, \mathrm{I}} * \operatorname{LOG}\left(\mathrm{HCONS}_{\mathrm{H}, \mathrm{I}}\right)\right) \\
& \text { UTILTOT }=\sum_{\mathrm{H}} \text { UTILITY }_{\mathrm{H}} \\
& \mathrm{INT}_{\mathrm{I}}=\sum_{\mathrm{J}} \mathrm{IO}_{\mathrm{J}, \mathrm{I}} * X_{\mathrm{I}} \\
& \mathrm{INTD}_{\mathrm{I}}=\sum_{\mathrm{J}} I O_{\mathrm{I}, \mathrm{J}} * X_{\mathrm{J}} \\
& \mathrm{SUBSIDY}=\sum_{\mathrm{I}} \mathrm{SUB}_{\mathrm{I}} * \mathrm{PX}_{\mathrm{I}} * X_{\mathrm{I}} \\
& \mathrm{VAT}=\sum_{\mathrm{I}}\left(\mathrm{TVD}_{\mathrm{I}} * \mathrm{PX}_{\mathrm{I}} * X_{\mathrm{I}}\right) \\
& +\sum_{\mathrm{I}}\left(\mathrm{PWN}_{\mathrm{I}} N_{\mathrm{I}} * \mathrm{TVN}_{\mathrm{I}} *\left(1+\mathrm{TN}_{\mathrm{I}}\right)\right) * \mathrm{ER} \\
& +\sum_{\mathrm{I}}\left(\mathrm{PWM}_{\mathrm{I}} * M_{\mathrm{I}} * \mathrm{TVM}_{\mathrm{I}} *\left(1+\mathrm{TM}_{\mathrm{I}}\right)\right) * \mathrm{ER} \\
& \mathrm{IMTAX}=\sum_{\mathrm{I}}\left(\mathrm{TM}_{\mathrm{I}} * \mathrm{PWM}_{\mathrm{I}} * M_{\mathrm{I}}\right) * \mathrm{ER}+\sum_{\mathrm{I}}\left(\mathrm{TN}_{\mathrm{I}} * \mathrm{PWN}_{\mathrm{I}} * N_{\mathrm{I}}\right) * \mathrm{ER} \\
& \mathrm{PPTREV}=\sum_{\mathrm{I}}\left(\mathrm{PPT}_{\mathrm{I}} * \mathrm{CAP}_{\mathrm{I}} * \mathrm{PK}_{\mathrm{I}}\right) \\
& \operatorname{EXTAX}=\sum_{\mathrm{I}}\left(\mathrm{TD}_{\mathrm{I}} * \mathrm{PX}_{\mathrm{I}} * X_{\mathrm{I}}\right) \\
& \text { OILDOMREV }=\sum_{\mathrm{I}}\left(\text { OILDOMR }_{\mathrm{I}} * \mathrm{PD}_{\mathrm{I}} * X_{\mathrm{I}}\right) \\
& \text { OILFORREV }=\sum_{\mathrm{I}}\left(\text { OILFORR }_{\mathrm{I}} * \mathrm{PE}_{\mathrm{I}} * X_{\mathrm{I}}\right) \\
& \operatorname{COYTAX}_{\mathrm{I}}=\sum_{\mathrm{I}}\left(\operatorname{COYTR}_{\mathrm{I}} * \mathrm{PK}_{\mathrm{I}} * \mathrm{CAP}_{\mathrm{I}} *\left(1-\mathrm{DEPR}_{\mathrm{I}}-\mathrm{PPT}_{\mathrm{I}}\right)\right)
\end{aligned}
$$




$$
\begin{aligned}
& \text { COYTAXTOT }=\sum_{\mathrm{I}} \text { COYTAX }_{\mathrm{I}} \\
& \text { GRTOT }=\text { VAT }+ \text { IMTAX }+ \text { COYTAXTOT }+ \text { PPTREV } \\
& + \text { OILDOMREV + OILFORREV + EXTAX - SUBSIDY } \\
& \text { GETOT }=\text { GRTOT }- \text { GOVSAV } \\
& \mathrm{SECGOV}_{\mathrm{I}}=\mathrm{GSEC}_{\mathrm{I}} * \mathrm{GETOT} / P_{\mathrm{I}} \\
& \text { GOVSAV }=\text { GOVSAVR } * \text { GRTOT } \\
& \operatorname{HSAV}_{\mathrm{H}}=\mathrm{HHYTOT}_{\mathrm{H}}-\sum_{\mathrm{I}} \mathrm{HCONS}_{\mathrm{H}, \mathrm{I}} \\
& \mathrm{FSAV}=\sum_{\mathrm{I}}\left(\mathrm{PWM}_{\mathrm{I}} * M_{\mathrm{I}}\right)+\sum_{\mathrm{I}}\left(\mathrm{PWN}_{\mathrm{I}} * N_{\mathrm{I}}\right)+\text { ROWDIVTOT } / \mathrm{ER}-\sum_{\mathrm{I}}\left(\mathrm{PWE}_{\mathrm{I}} * E_{\mathrm{I}}\right)+\text { WALRAS }
\end{aligned}
$$

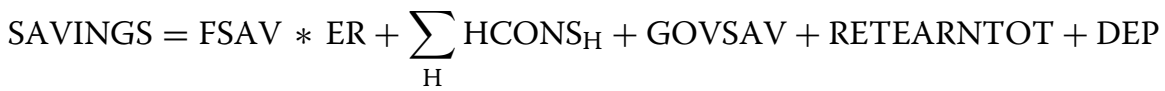

$$
\begin{aligned}
& \mathrm{ID}_{\mathrm{I}}=\mathrm{KSH}_{\mathrm{I}} * \frac{\mathrm{INVEST}}{P_{\mathrm{I}}} \\
& \mathrm{RGDP}=\sum_{\mathrm{H}} \mathrm{TOTHCONS}_{\mathrm{H}}+\sum_{\mathrm{I}} \mathrm{ID}_{\mathrm{I}}+\sum_{\mathrm{I}} \mathrm{SECGOV}_{\mathrm{I}}+\sum_{\mathrm{I}} E_{\mathrm{I}}-\sum_{\mathrm{I}}\left(M_{\mathrm{I}} *\left(1-\mathrm{TM}_{\mathrm{I}}\right)\right. \\
& \left.*\left(1-\mathrm{TVM}_{\mathrm{I}}\right)\right)-\sum_{\mathrm{I}}\left(N_{\mathrm{I}} *\left(1-\mathrm{TN}_{\mathrm{I}}\right) *\left(1-\mathrm{TVN}_{\mathrm{I}}\right)\right)
\end{aligned}
$$

System constraints' block

$$
Q_{\mathrm{I}}=\mathrm{INTD}_{\mathrm{I}}+\sum_{\mathrm{H}} \mathrm{HCONS}_{\mathrm{H}, \mathrm{I}}+\mathrm{SECGOV}_{I}+\mathrm{ID}_{\mathrm{I}}
$$

INVEST $=$ SAVINGS

$$
\begin{aligned}
& L=\sum_{\mathrm{I}} \mathrm{LAB}_{\mathrm{I}} \\
& K=\sum_{\mathrm{I}} \mathrm{CAP}_{\mathrm{I}}
\end{aligned}
$$

\section{Dynamic equations' block}

$$
\begin{aligned}
& \mathrm{CAP}_{\mathrm{IT}}=\mathrm{CAP}_{\mathrm{I}(\mathrm{T}-1)}+\mathrm{ID}_{\mathrm{I}(\mathrm{T}-1)}-\mathrm{DEP}_{\mathrm{I}(\mathrm{T}-1)} \\
& \mathrm{FSAV}_{\mathrm{T}}=(1+\mathrm{PGR}) * \mathrm{FSAV}_{(\mathrm{T}-1)}
\end{aligned}
$$


$L_{\mathrm{T}}=(1+\mathrm{PGR}) * L_{(\mathrm{T}-1)}$

$\operatorname{OILDOMREV}_{\mathrm{T}}=(1+\mathrm{OGR}) * \operatorname{OILDOMREV}_{(\mathrm{T}-1)}$

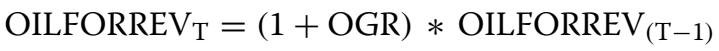

Received: 13 July 2018 Accepted: 11 June 2019

Published online: 22 June 2019

\section{References}

Ajakaiye DO (1996) Macroeconomic effects of VAT in Nigeria: a computable general equilibrium analysis. Final report, submitted to African Economic Research Consortium (AERC), p 35

Aminu A (2006) Incidence and efficiency effects of non-oil taxes in Nigeria. Dissertation, University of Ibadan, Ibadan, Nigeria

Aminu A (2007) A computable general equilibrium analysis of value-added tax policy in Nigeria. Paper presented at a Workshop jointly organised by the United Nations Development Programme and National Planning Commission as part of preparation for MDG-Based Generic Macroeconomic Framework for Nigeria, Bolingo Hotel, Abuja, November 13 June, 2007

Armington PS (1969) A theory of demand for products distinguished by place of production. Int Monet Fund Staff Pap 16(1):159-177

Bye B, Strom B, Avitsland T (2003) Welfare effects of VAT reforms: a general equilibrium analysis. Discussion Papers No. 343 March 2003, Statistics Norway, Research Department. http://www.ssb.no. Accessed 25 March 2017

Carroll R, Cline R, Neubig T, Diamond J, Zodrow G (2010) The macroeconomic effects of an add-on value-added tax (Ernst and Young). http://www.bakerinstitute.org/media/files/Research/bbb83cf0/TEPP-pub-NRFValueAddedTax-10071 0.pdf. Retrieved 14 Apr 2017

Central Bank of Nigeria (2018) Statistical bulletin. Central Bank of Nigeria, Abuja

Dervis K, de Melo J, Robinson S (1982) General equilibrium models for development policy. World Bank, Washington, DC Ekeocha PC (2011) Modelling the potential economic effects of tax policy reform in Nigeria: simulation analysis using the CGE model. Paper presented at the AGRODEP members meeting and workshop June 6-8, 2011 Dakar Senegal

Emini CA (2004) Long run versus short run effects of a value added tax: a computable general equilibrium assessment for Cameroon. http://www.crefa.ecn.ulaval.ca/cahier/liste00.html. Retrieved 20 March 2017

Erero JL (2015) Effects of increases in value-added tax: a dynamic CGE approach, ERSA Working Paper 558. https://econr sa.org/publications/working-papers/effects-increases-value-added-tax-dynamic-cge-approach. Retrieved $10 \mathrm{Apr}$ 2017

Federal Inland Revenue Service (2019) Revenue collected from taxes. https://www.firs.gov.ng/TaxResources/TaxStatist icsReports and https://www.firs.gov.ng/sites/Authoring/Lists/Content/themes/pdf/tax\%20statistics/2018\%20Statisti cs/2018\%2001\%20Tax\%20Revenue\%20Collection\%20Statistics.pdf. Accessed 31 Jan 2019

Felici F, Gesualdo M (2014) Fiscal extension to ORANI-IT: a computable general equilibrium model of Italy, Working Paper No. 8 August 2014. Ministry of Economy and Finance, Department of the Treasury. http://www.dt.tesoro.it/expor t/sites/sitodt/modules/documenti_it/analisi_progammazione/working_papers/WP_N._8_-_2014.pdf. Retrieved 5 July 2018

Giesecke JA, Tran HN (2009) Modelling value-added tax in the presence of multi-production and differentiated exemptions. Paper presented at the twelfth annual conference on global economic analysis, Santiago, Chile, June 10-12, 2009

Go DS, Kearney M, Robinson S, Thierfelder K (2005) An analysis of South Africa's value-added tax, WPS3671, World Bank Policy Research Working Paper 3671

Kearney M, van Heerden JH (2003) A static, stylised CGE model applied to evaluate the incidence of value-added tax in South Africa www up.acza/UserFiles/. Retrieved 25 June 2018

Levin J, Sayeed Y (2014) Welfare impact of broadening VAT—the case of Bangladesh, Working Paper, ISSN 1403-0586, Örebro University School of Business

Nakamba-Kabaso PM (2010) Reforming the value-added tax in Zambia. Dissertation, University of the Witwatersrand, South Africa

Nigeria Customs Service (2019) Customs and excise duties' revenue collected in press releases. www.nigeriacustoms.gov. ng. Accessed 31 Jan 2019

Sajeewani D, Meng X (2017) Macroeconomic and welfare effects of VAT in GCC countries: general equilibrium analysis. In: Proceedings of the 47th international business research conference, 13-14 December 2017, Hayatt Regency, Osaka, Japan. https://wbiworldconpro.com/uploads/osaka-conference-2017-december/economics/1513252838 .pdf. Retrieved 5 July 2018

Zee HH (1995) Taxation and efficiency. In: Shome P (ed) Tax policy. IMF, Washington, DC

\section{Publisher's Note}

Springer Nature remains neutral with regard to jurisdictional claims in published maps and institutional affiliations. 